Journal of Invertebrate Pathology

July 2017, Volume 147, Pages 118-135

http://dx.doi.org/10.1016/i.jip.2017.01.009

http://archimer.ifremer.fr/doc/00371/48206/

(C) 2017 Elsevier Inc. All rights reserved.

\title{
Viruses infecting marine molluscs
}

\author{
Arzul Isabelle ${ }^{1}$, Corbeil Serge ${ }^{2}$, Morga Benjamin ${ }^{1}$, Renault Tristan ${ }^{3,{ }^{*}}$
}

${ }^{1}$ Laboratoire de Génétique et Pathologie des Mollusques Marins. IFREMER. Station La Tremblade.

17390 La Tremblade. France

${ }^{2}$ CSIRO Australian Animal Health Laboratory. 5 Portarlington Road, Geelong East, Victoria, 3220.

Australia

${ }^{3}$ Département Ressources Biologiques et Environnement. IFREMER. Centre Atlantique - Rue de l'lle

d'Yeu - BP 21105 - 44311 Nantes Cedex 03. France

* Corresponding author : Tristan Renault, email address : Tristan.Renault@ifremer.fr

\begin{abstract}
:
Although a wide range of viruses have been reported in marine molluscs, most of these reports rely on ultrastructural examination and few of these viruses have been fully characterized. The lack of marine mollusc cell lines restricts virus isolation capacities and subsequent characterization works. Our current knowledge is mostly restricted to viruses affecting farmed species such as oysters Crassostrea gigas, abalone Haliotis diversicolor supertexta or the scallop Chlamys farreri. Molecular approaches which are needed to identify virus affiliation have been carried out for a small number of viruses, most of them belonging to the Herpesviridae and birnaviridae families. These last years, the use of New Generation Sequencing approach has allowed increasing the number of sequenced viral genomes and has improved our capacity to investigate the diversity of viruses infecting marine molluscs. This new information has in turn allowed designing more efficient diagnostic tools. Moreover, the development of experimental infection protocols has answered some questions regarding the pathogenesis of these viruses and their interactions with their hosts. Control and management of viral diseases in molluscs mostly involve active surveillance, implementation of effective bio security measures and development of breeding programs. However factors triggering pathogen development and the life cycle and status of the viruses outside their mollusc hosts still need further investigations.
\end{abstract}




\section{Graphical abstract}

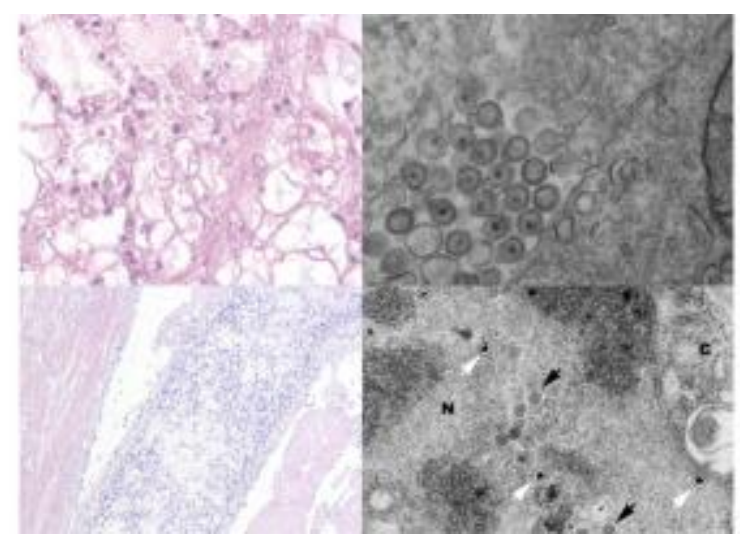

\section{Highlights}

- Among viruses reported in marine molluscs, few of them have been fully characterized. The currently best known viruses infecting farmed marine molluscs belong to Malacoherpesviridae. The lack of marine mollusc cell lines restricts virus isolation capacities and characterization works. The sequencing of partial or total viral genomes allows studying diversity and designing diagnostic tools. Control measures include selective breeding enhancing anti-viral resistance.

Keywords : Molluscs, viruses, diseases, Herpesviridae, bivalve, abalone 


\section{Introduction}

Marine mollusc production is an increasingly important contributor to global food supply. Clams and cockles represent the first group of produced marine bivalves in the world with 5 millions of tons produced in 2012. It is closely followed by oysters while world mussels and pectinids production is less than 2 million tons (FAO, 2015). Although, in terms of production tonnage, abalone contributes a relatively small proportion of this aquaculture production, it is one of the most highly prized seafood delicacies in many parts of the world, particularly in Asia and, therefore, in terms of the value of production, is very important to many countries (Cook, 2014).

Despite this enjoyable situation, compared to other aquaculture activities the shellfish industry has shown rather slow growth notably because of limiting factors which primarily include infectious diseases including viral diseases (Bower 2010). For example, in Europe, irido-like virus infections led to the almost total extermination of the Portuguese oyster, $C$. angulata, in French and European Atlantic waters in the early 1970's (Comps et al., 1976; Comps \& Bonami, 1977). Since 1991, viruses belonging to the Herpesviridae family have been associated with high mortality rates of Crassostrea gigas hatchery-reared larvae and spat in France but also in New Zealand, USA and Mexico (Renault and Novoa 2004). Wild and farmed abalones have experienced important mortality in Asia since the 90ies and subsequently in Australia since 2005. These mortalities have been attributed to a herpesvirus. In addition to these examples, many mortality events of marine molluscs remain unexplained and might be due to viruses.

These examples highlight the adverse effect of viruses on bivalve production. In addition considering that shellfish are filter feeders, they bioaccumulate in their tissues viruses present 
in the sea water and that might be pathogens for humans and higher vertebrates (Meyers, 1984). These viruses apparently do not affect bivalves but can indirectly impact the shellfish industry.

The fast growing development of New Generation Sequencing approach has started revealing the high diversity of viruses present in sea water (Brum et al. 2015; Martinez Martinez et al. 2014). A liter of seawater contains at least 100 billion viruses - the vast majority of which remain unidentified and uncharacterized (Weitz and Wilhelm, 2012). This diversity could be seen as a reserve of potential harmful pathogens for bivalves in the context of dysregulation of the ecosystem.

In the present paper we will consider viruses which infect marine molluscs and replicate in their tissues. Although a wide range of viral families including Herpesviridae, Papovaviridae, Togaviridae, Retroviridae, Reoviridae, Birnaviridae, and Picornaviridae (Renault and Novoa 2004, Meyers et al. 2009) have been reported in marine molluscs few of them have been fully characterized and most of these reports rely on ultrastructural examination. The lack of marine mollusc cell lines certainly restricts virus isolation capacities and subsequent characterization works. Molecular approaches which are needed to clearly identify virus affiliation have been carried out for a small number of viruses, most of them belonging to the Herpesviridae family.

The present paper aims to provide updated information on viruses pathogenic for marine molluscs in terms of diversity, pathogenesis, diagnosis, life cycle, interactions with their hosts and biosecurity. Most of information will concern members of the Herpeviridae family, however where and when possible, examples of members of other family will be included. 


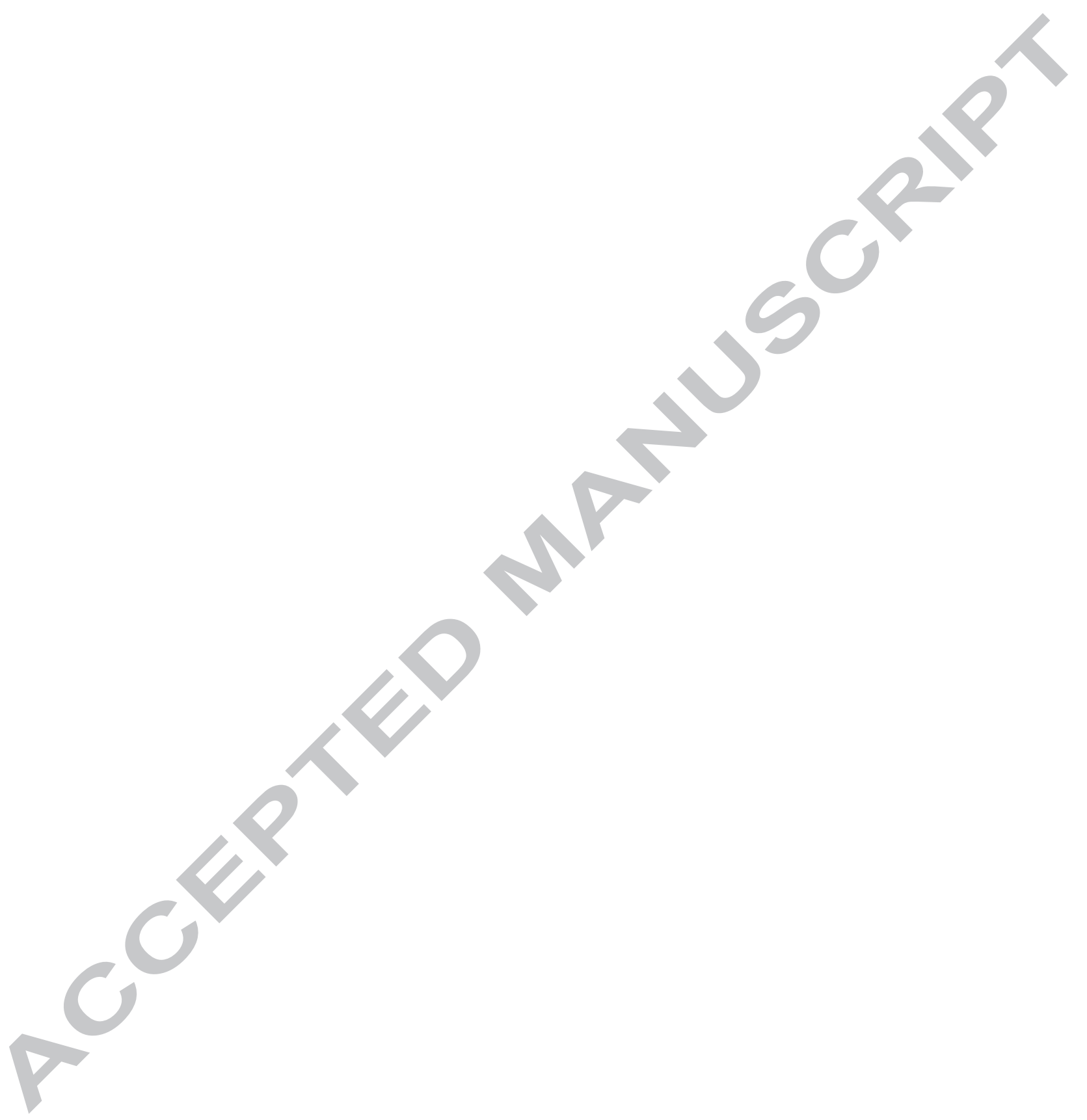




\section{Genetic diversity of viruses infecting marine molluscs}

There is currently a lack of molecular information concerning these viruses as the basic method for identification and examination of suspect samples remains histology. This technique enables the identification of cellular changes associated with viral infections without providing conclusive virus identification. Transmission electron microscopy examination was carried out providing information on viral ultrastructural features and putative assignment to particular viral families. However, only a few of them have been purified allowing an access to their genome and molecular characterization through sequencing. It is the case for birnairuses and herpesviruses infecting marine molluscs. As a consequence, both these virus groups have been studied more extensively than other mollusc viruses. They have been subjected to examination at molecular, epidemiological and ecological levels. Although birnaviruses have been detected in various marine molluscs, their infectivity for shellfish should still be regarded as weak or hypothetical. On the contrary, herpesviruses infecting marine molluscs are highly pathogenic.

\section{Birnaviruses}

Birnaviruses have been isolated from different bivalve species worldwide using different fish cell lines (Hill, 1976; Lo et al., 1988). Tellina virus 1 (TV-1) was isolated on the BF-2 (bluegill fry) fish cell line from Tellina tenuis in Great Britain (Hill, 1976) and assigned to the Birnaviridae family (Dobos et al., 1979). A virus assigned to the Birnaviridae has been also identified from cultured hard clams, Meretix lusoria, in Taiwan (Lo et al., 1988). Suzuki et al. (1998a) isolated a virus from Japanese pearl oysters (Pinctada fucata) presenting mass mortality named "Marine birnavirus" (MABV) (Suzuki et al., 1998a). A birnavirus was also isolated from Agemaki (Jack Knife Clam) Sinovacura consticta in Japan (Suzuki et al., 
1998c). More recently, viruses interpreted as aquabirnaviruses were reported from Geoduck clams, Panope abrupta, and litteneck clams, Protothaca staminea, collected in Alaska (Meyers et al., 2009). Both viruses were not associated with abnormal mortality nor lesions detected by histology in the collected animals (Meyers et al., 2009).

MABV have been defined as a group belonging to the genus Aquabirnavirus and forming an independent genogroup to the infectious pancreatic necrosis virus (IPVN) infecting salmonids. Although MABV are relevant fish pathogens, they have also been isolated from a variety of marine shellfish (Inaba et al., 2009). Viruses isolated from shellfish and fish seem similar based on serological and genomic properties (Suzuki et al., 1997b; 1998b). High homologies were reported in the VP2/NS junction region of the virus genome between fish and shellfish isolates (Suzuki et al., 1998a; Suzuki et al., 1998c; Zhang and Suzuki, 2003; Zhang and Suzuki, 2004; Inaba et al., 2009). All MABV are grouped in the same genogroup in the Aquabirnaviruses (Zhang and Suzuki, 2004). Although MABV and IPNV resemble each other, genogrouping based on the nucleotide sequence of the VP2/NS junction region separates them (Hosono et al., 1996). More recently, Nobiron et al. (2008) established that TV-1 is phylogenetically distant from all already known birnaviruses and defines a new genetic cluster among the birnaviruses.

Although the pathogenicity of certain MABV strains appears to be weak in shellfish, stressors such as changes in temperature, spawning and exposure to heavy metals can result in mortality events by increasing host susceptibility in some mollusc species (Meretrix lusoria, Sinovacura constricta and P. fucata). MABV may be considered as opportunistic pathogens able to induce a disease in marine molluscs under stressful conditions (Chou et al., 1994; 1998). Although MABV isolated from shellfish appear to be pathogenic to fish, assays to reproduce experimentally the infection in molluscs using birnavirus-like particles isolated on fish cell lines have shown inconsistent results. 


\section{Herpesviruses}

Herpesviruses have been associated to mortality outbreaks resulting in high losses in several marine mollusc species, including the Pacific oyster, Crassostrea gigas, worldwide (Hine et al., 1992; Renault et al., 1994a and b; Burge et al., 2007; Vasquez-Yeomans et al., 2010). A herpesvirus has been purified from naturally infected larval Pacific oysters collected in 1995 in a French commercial hatchery (Le Deuff and Renault, 1999) and its genome entirely sequenced (Davison et al., 2005) (GenBank accession number AY509253). This virus has been classified as ostreid herpesvirus type $1(\mathrm{OsHV}-1)$ within the Malacoherpesviridae family from the Herpesvirales order (Davison et al., 2009). The OsHV-1 genome is a doublestranded DNA of about $207 \mathrm{kbp}$ (Davison et al., 2005). The overall genome organization is $T R_{L}-U_{L}-I R_{L}-X-I R_{S}-U_{S}-T R_{S}$ in which $T R_{L}$ and $I R_{L}$ are inverted repeats flanking a unique region, $\mathrm{U}_{\mathrm{L} . .}$. However, a certain diversity of the viral genome was reported by Davison et al. (2005) as a small proportion of OsHV-1 genomes either lack the X sequence or contain an additional $\mathrm{X}$ sequence at the left terminus. Moreover, a $4.8 \mathrm{kbp}$ region of $\mathrm{U}_{\mathrm{L}}$ in inverse orientation was reported in approximately $20-25 \%$ of genomes (Davison et al., 2005). $\mathrm{U}_{\mathrm{L}}$ and $\mathrm{U}_{\mathrm{S}}$ were reported presenting two orientations in approximately equimolar amounts in viral DNA (Davison et al., 2005). The $\mathrm{IR}_{\mathrm{L}}-\mathrm{IR}_{\mathrm{S}}$ junction is also not unique (Davison et al., 2005). OsHV-1 genomic variants have been reported in different bivalve species in various geographical locations (Arzul et al., 2001a and b; Renault et al., 2001a and b; Friedman et al., 2005; Moss et al., 2007). A variant called "Var" was reported in 1997 during one episode of mortality affecting both larval Pacific oysters, C. gigas, and larval Manila clams, Ruditapes philippinarum(Arzul et al., 2001b; Renault et al., 2001a and b). Renault et al. (2012) reported that two C. gigas larval samples collected in a single commercial hatchery in 1993 presented high homologies with the variant Var. This variant was quite rarely detected in France and 
could be a virus infecting first clams. Interspecies transmission may be promoted through intensive farming conditions under which different bivalve species (oysters, clams) are kept at the same time in unnaturally close proximity.

Since 2008, massive mortality outbreaks among Pacific oysters, C. gigas, are reported in Europe (EFSA, 2010) in relation to the detection of a particular genotype called $\mu$ Var (Segarra et al., 2010). Several differences in two genome areas (ORF4 and ORFs 42/43) including a deletion of 12 bp in a microsatellite located up-stream of the ORF4 characterize this variant when compared with the "reference" type genome (GenBank accession $n^{\circ}$ AY509253) (Segarra et al., 2010). The variant $\mu$ Var has been reported initially in France (Segarra et al., 2010; Martenot et al., 2011; Renault et al., 2012; Martenot et al., 2013) and Ireland (Peeler et al., 2012) in 2008-2009, and subsequently in Great Britain in 2010 (EFSA, 2010; Lynch et al., 2012). The presence of the variant $\mu$ Var was also reported more recently in Spain in association with mortality events (Roque et al., 2012). Additionally, the reference type and the variant $\mu$ Var were simultaneously detected in Italy in oysters originating from France in the absence of any pathological sign (Dundon et al., 2011). Mortality outbreaks were also reported recently in New Zealand and Australia (OIE, 2011a and b; Paul-Pont et al; 2014) in association with the detection of variants closely related to the variant $\mu$ Var (Renault et al., 2012; Keeling et al., 2014). In this context, the term $\mu$ Var needs to be used to define a single variant presenting all the mutations reported by Segarra et al. (2010). These results raise questions about the concomitant emergence of closely related genotypes (microvariants) in different parts of the world.

The genome of a herpesvirus infecting cultured scallops Chlamys farreri in China has been also sequenced (GenBank accession number GQ153938). This virus has been detected in association with mass mortality events affecting scallops since the middle 1990s. It has been called acute viral necrosis virus (AVNV). The AVNV genome is 210,993 bp and its 
organization appeared similar to that of OsHV-1. 123 putative open reading frames (ORFs) were identified: 86 ORFs show 40 to $99 \%$ amino acid identity to those of OsHV-1, and 29 genes are completely matching in size and orientation with the two viruses (Ren et al., 2013). AVNV have been identified as OsHV-1 based on its genome sequence and its genome organisation (100\% identities covering 97\% of the complete genome) (Ren et al, 2013). AVNV and OsHV-1 demonstrated related hosts, C. farreri and Pecten maximus (Arzul et al., 2001a), respectively. Although OsHV-1 was first described in C. gigas larvae (Le Deuff \& Renault, 1999; Davison et al., 2005), data show that OsHV-1 can infect different bivalve species (Arzul et al., 2001a and b; Renault et al., 2001a and b)Xia et al. (2015) reported recently the complete genome sequence of OsHV-1 associated with mortality of Scapharca broughtonii broodstocks in China. The DNA sequence is $95.2 \%$ and $97.3 \%$ identical to that of OsHV-1 reference type and AVNV, respectively. The genomic organization showed the absence of the unique region $(\mathrm{X}, 1.5 \mathrm{~Kb})$ between IRL and IRS which is different from that of OsHV-1 reference type and AVNV. On the basis of nucleotide sequences analysis, the virus infecting S. broughtonii broodstocks in China appeared as closely related to AVNV.

Renault et al. (2012) analysed 63 OsHV-1 specimens collected in France from 1993 to 2010 and six samples originated from Ireland, the USA, China, Japan and New Zealand to better describe OsHV-1 genetic diversity. Different primer pairs targeting different ORFs were tested in a preliminary approach (figure 1). Three areas of the virus genome (ORF4, ORFs 35/36/37/38 and ORFs 42/43) were selected for direct sequencing of PCR products. The analysis of the sequences of these particular regions, both independently and as concatemerized units, made it possible to define different sub-groups (Renault et al., 2012). Xhether the reference type and the variant $\mu$ Var share a common ancestor, the variant $\mu$ Var seems not to be directly derived from the reference type (Renault et al., 2012). All samples identified as being the variant $\mu$ Var demonstrated a large deletion (605 bp) as well as samples 
collected in China, the USA, Japan and New Zealand in the ORF 36/37/38 area. This 605 bp deletion reported for the $\mu$ Var and related variants could affect virus virulence with the lack of two genes and the modification of a third one. However,genetic changes including large deletions have been most frequently reported in attenuated strains in comparison to virulent ones (Lomniczi et al., 1987; Spatz \& Silva, 2007; Labanov et al., 2010). ORF36 encodes a putative membrane protein, ORF37 a small protein of unknown function, and ORF38 a RING finger protein. RING finger proteins have been shown to play a key role in transregulatory functions in vertebrate herpesviruses (Moriuchu et al., 1994; Cohen \& Ngyen, 1998). The RING finger domain of ICP0 and homologs from alpha herpesviruses is required for the activation of quiescent genomes blocking silencing of viral DNA (Gu \& Roizman, 2009; Everett et al., 2010; Ferenczy et al., 2011). The deletion of a part of the ORF38 may affect viral activities allowing the viral infection to be better expressed. However, as more than $70 \%$ OsHV-1 genes encode putative proteins of unknown functions without homologies with proteins in databases (including ORF36 and ORF37 proteins), little is known about the factors that may affect OsHV-1 virulence. Further studies particularly based on RNA silencing and the use of recombinant virus proteins need to be developed in order to determine the role of the proteins encoded by ORFs 36,37 and 38 in virulence.

Renault et al (2012) reported that virus samples collected in France from 2003 to 2008 showed differences in comparison with the reference type. These results suggest that different OsHV-1 variants coexisted in France. Van Regenmortel (2008) wrote "the genome of a virus cannot be defined by a unique sequence corresponding to a so-called wild type but consists of a distribution of mutant sequences, each one differing from the sequence of the clone". Thus, wild-type virus populations are often considered to exist as a collection of individual viruses that make up the quasispecies (Spatz \& Silva, 2007; Spatz \& Rue, 2008). 
Specimens collected in France since 2008 and identified as being the variant $\mu$ Var and specimens collected in China, Japan and New Zealand grouped together suggesting a common origin (Renault et al., 2012). Although the variant $\mu$ Var was described first in France in 2008 (Segarra et al., 2010), this variant or closely related forms might exist before 2008 outside Europe. Based on phylogenetic relationships, the variant $\mu$ Var reported in Europe since 2008 may be derived from virus specimens originating from the Pacific area. These results were supported by the analysis of archived material originating from New Zealand suggesting the presence of a variant closely related to the variant $\mu$ Var in Pacific oyster samples collected in 2005 during a mortality outbreak (Renault et al., 2012). Shimahara et al. (2012) detected variable types of OsHV-1 in main oyster-producing areas of Japan, using PCR targeting a C2/C6 fragment and sequencing PCR products. These authors reported 23 different nucleotide sequences, showing $96 \%$ to $99 \%$ similarity to the reference virus type. Although 18 sequences among these 23 demonstrated the deletion in the microsatellite area, one of the mutation characterizing the variant $\mu$ Var, all PCR products showed two conserved nucleotides that were shared with the reference OsHV-1 and not with the variant $\mu$ Var. Variable types of OsHV-1 were thus present in oysters in Japan.

Bai et al. (2016) carried a study to identify and characterize OsHV-1 associated with mass mortality outbreaks in S. broughtonii broodstocks in China. Based on sequence analysis of the C2/C6 region of PCR products from S. broughtonii samples collected in 2012 and 2013, these authors reported 5 newly described OsHV-1 variants, which were closely related to each other. Phylogenetic analysis of the 5 virus variants and 48 virus variants reported in previous studies identified 2 main phylogenetic groups as previously reported by Renault et al. (2012), and the 5 virus variants grouped with the reference type and AVNV (Bai et al., 2016).

Outbreaks of Haliotis herpesvirus (HaHV) infection were reported in cultured abalone, Haliotis diversicolor supertexta in Taiwan in association with mass mortality (Chang et al., 
2005). The disease was reported only in $H$. diversicolor supertexta, while cohabitating Japanese black abalone Haliotis discus remained normal (Chang et al., 2005). Mortality events were also observed in blacklip abalone Haliotis rubra, greenlip abalone H. laeviga, and their hybrids in Australia in association with herpesvirus detection (Hooper et al., 2007). In Australia, the initial mass mortality outbreak occurred on a farm during summer 2005/06 and subsequently appeared to spread to wild populations. Herpesvirus infection outbreaks in both farmed and wild abalone populations in Australia are associated with the rapid onset of high mortality rates (up to 90\%) in all age classes.

Abalone herpesvirus (AbHV) particles have been purified from infected abalone from Victoria (Tan et al., 2008) allowing viral DNA extraction and complete sequencing. Comparison of nucleotide sequences of AbHV VIC and OsHV-1 (Davison et al., 2009; Le Deuff \& Renault, 1999) over common coding regions identified similarities ranging from $19 \%$ to $53 \%$, indicating that these viruses share a low level of sequence similarity (Savin et al., 2010). AbHV has been assigned tentatively as a second member of the Malacoherpesviridae. It is not known whether the Australian virus is the same as, or different from, the virus found in Chinese Taipei. Recent genome sequence analyses have indicated that a number of genotypic variants are present in Australia (Cowley et al., 2011). Corbeil et al. (2016) evaluated the relative pathogenicity of 5 known variants of AbHV on abalone stocks from different states in Australia. The 5 variants caused disease and mortality in all abalone stocks tested (greenlip, blacklip and brownlip). 


\section{Pathogenesis of viruses infecting marine molluscs}

Although many viruses have been observed in molluscs and tentatively described by transmission electron microscopy, few of them have been formally associated with clinical signs and tissular or cellular lesions. Besides herpesvirsuses which have been more extendedly investigated, most of the available histological descriptions concern viruses which induce visible lesions under the light microscope such as irido-like viruses and papova-like viruses

\section{Irido-like viruses}

Several irido-like viruses have been reported in bivalves in different countries around the world. These viruses were interpreted as the cause of the gill necrosis virus (GNV) disease and hemocyte infection virus (HIV) disease in the Portuguese oyster Crassostrea angulata in France (Comps et al. 1976; Comps 1978; Comps and Duthoit 1979; Comps 1980) and of the oyster velar virus disease (OVVD) in hatchery-reared larval Pacific oysters on the west coast of North America (Elston 1979; Elston and Wilkinson 1985).

In $C$. angula, the first gross sign of the GNV disease was the appearance of one or several yellow spots on gills and labial palps. Affected tissues became brown and eventually left a perforation in the gills. More advanced stages of the infection were associated with gill indentation or even a total destruction of affected gill filaments. Yellow or green pustules also developed on the adductor muscle and on the mantle. Mantle perforation could occur as on the gills (Alderman and Gras 1969; Comps 1969 and 1970). Similar but less extensive lesions could be observed in infected $C$. gigas.

Although HIV disease affected adult oysters from 1970 to 1973 in France, no distinctive signs were reported. However, histological examination, revealed considerable degeneration of connective tissues and the presence of atypical cells interpreted as infected hemocytes. 
When affected by OVVD, Pacific oyster larvae appear unable to execute normal active movements. The disease results in the sloughing of ciliated velar epithelial cells forming the characteristice "blisters" (Elston and Wilkinson 1985). Infected velar epithelial cells which are in the process of detaching from the velum appear as blebs along the periphery of the velum. Other cells lose cilia and the larvae become unable to move normally (Elston and Wilkinson 1985). Histologically the disease is characterized by the presence of intracytoplasmic inclusion bodies and separation and detachment of infected cells from surrounding tissues. The intracytoplasmic inclusions bodies, $1.2-4 \mu \mathrm{m}$ in diameter, are located most commonly in ciliated velar epithelium. Lesions are observed in velar, oral and distal esophageal epithelia (Elston and Wilkinson 1985). Nuclear and mitochondrial swelling accompanies the development of the infection.

By electron microscopy, intracytoplasmic icosahedral virions of 300-350 nm in diameter are observed in hypertrophied gill cells or infected hemocytes (Comps et al. 1976; Comps 1978; Comps and Duthoit 1979). Virions consist of electron-dense core, 190 to $250 \mathrm{~nm}$ in diameter, surrounded by an electron-lucent zone and another dense layer $45 \mathrm{~nm}$ in thickness. The viral particles are enclosed within two membranes separated by a clear zone.

In the case of OVVD, electron microscope examinations reveal viroplastic inclusion bodies in velar, oral and epithelial tissues of diseased larvae (Elston 1979; Elston and Wilkinson 1985). The viroplasms are typically granular and electron dense and correspond to intracytoplasmic inclusions visible at the light microscopy level. Initiation of virion formation is observed at the periphery of some viroplasms (Elston 1979; Elston and Wilkinson 1985).

Viral particles are similar to virions observed in GNV or HIV diseases (Elston and Wilkinson 1985) include viral particles. 
Ultrastructural features and assemblage of viral particles within the cytoplasm support that these viruses belong to the Iridoviridae. However, molecular characterization is required to assess their identity.

\section{Papilloma or Polyoma-like viruses}

Viral gametocytic hypertrophy (VGH) has been reported in different oyster species in different parts of the world usually with low prevalence and low infection intensity. Farley (1985) observed VGH in hypertrophied cells of gonad tubules of Crassostrea virginica sampled in various US states and reported on histologically similar lesions seen in C. gigas and Ostrea lurida from Korea, Japan, Oregon and Washington and similar lesions in $C$. rhizophorae from Puerto Rico. He described non-enveloped, icosahedral viral particles 50 to $55 \mathrm{~nm}$ in diameter in these hypertrophied cells. Similar viral particles were also described in basophilic inclusions associated with VGH in the gonad tissue of Crassostrea gigas in Southern Korea (Choi et al. 2004). Icosahedral non-enveloped viral particles, 44 to $56 \mathrm{~nm}$ in diameter, which are characteristics of the Papillomaviridae and Polyomaviridae families, have also been reported in C. gigas in France (Garcia et al. 2006) and Ireland (Cheslett et al. 2009). Both male and female gametes can display hypertrophy and basophilic inclusions are observed in gamete nuclei (Garcia et al. 2006). The frequency of detection and the intensity of infection are usually very low and these descriptions are not associated with macroscopic signs or increased mortality rates (Garcia et al. 2006). Interestingly, VGH is not associated with sign of host defense reaction, suggesting that the viral particles have a weak impact on oysters.

\section{Herpesviruses}


Infection by OsHV-1 may cause an acute disease. Sudden and high mortalities are observed in a short period (less than one week) often during summer time (Garcia et al. 2011). Experimentally, challenged animals die within a few days (Schikorsy et al. 2011a). Clinical signs may be dead or gaping bivalves and infected hosts may be slow to close their valves when disturbed but these signs are not specific to infection with OsHV-1. Infected larvae show a reduction in feeding and swimming activities (Hine et al. 1992; Nicolas et al. 1992). Velum of moribund larvae is less extended than healthy larvae. Free pieces of velum may be observed in tank water. Shortly before death infected larvae settle at the bottom of the tanks. In infected blood ark shell (Scapharca[Anadara] broughtonii),clinical signs included slow response, gaping valves and pale visceral mass (Bai et al. 2016)

Histologically, the most consistent features of infection with OsHV-1 are nuclear changes including hypertrophy, nuclear margination and pyknosis (figure 2). The infection-associated lesions in spat or larvae are mainly observed in connective tissues in which fibroblastic-like cells exhibit enlarged nuclei with perinuclear chromatin (Hine et al. 1992; Nicolas et al. 1992; Renault et al. 2001a,b); (Renault et al. 1994a,b; Renault et al. 2000b). Highly condensed nuclei were also reported in other cells interpreted as hemocytes. Some nuclei show peculiar patterns of chromatin with a ring-shape or crescent-shape characteristic of apoptosis. These cellular abnormalities are not associated with massive hemocyte infiltration. However, swollen hemocytes with a small nucleus to cytoplasm ratio were noted circulating in the digestive gland, mantle, and connective tissue and diffuse hemocyte infiltration and lysed connective tissue were sometimes reported (Burge et al. 2006; Jenkins et al. 2013).

In infected oysters, some authors reported morphological changes in digestive tubule epithelia including cubodial metaplasia, tubule dilation and diapedesis (Burge et al. 2006; Jenkins et al. 2013; Keeling et al. 2014; Lopez-San Martin et al 2014). Jenkins et al. (2013) reported 
multifocal erosive and focally extensive ulcerative lesions in the mantle, palp and gill epithelium of Crassostrea gigas. Whilst Cowdry type A inclusions (eosinophilic intranuclear inclusions with perinuclear chromatin) are typical of many herpesvirus infections they have never been reported following histological examination of infected Pacific oysters (Arzul et al., 2002; Burge et al. 2006; Jenkins et al. 2013; Renault et al., 1994a,b). Interestingly, large intranuclear acidophilic inclusions similar to Cowdry type A inclusions have been reported in the oyster species including Ostrea edulis (Comps and Cochennec, 1993; da Silva et al. 2008, figure 3) and O. angasi (Hine and Thorne 1997).

In infected blood ark shell, microscopic changes included lysed connective tissue, dilation of the digestive tubules, eosinophilic inclusion bodies, nuclear chromatin margination and pyknosis (Bai et al. 2016).

Transmission electron microscopy examination of infected Crassostrea gigas spat and larvae revealed the presence of virus particles in fibroblastic-like cells throughout connective tissues especially in mantle, labial palps, gills and digestive gland (Renault et al., 1994b; Renault et al., 1995; Schikorski et al., 2011a, figures 4 and 5). Virogenesis begins in the nucleus of infected cells where empty capsids and nucleocapsids containing an electron-dense, toroidal or brick-shaped core are observed. These particles are circular or polygonal in shape, 70 to 80 nm in diameter (Hine et al. 1992; Nicolas et al. 1992; Renault et al. 2001a,b). Core and capsid are separated by an electron-lucent gap of approximately $5 \mathrm{~nm}$ with fine fibrils spanning the lucent-space from core to capsid.

Viral particles then pass through the nuclear membrane into the cytoplasm. Intracytoplasmic particles are similar to nuclear ones and sometimes have a trilaminar unit-membrane. They can be free in the cytoplasm or grouped within cytoplasmic vesicles 
Finally, enveloped particles are released at the cell surface. Extracellular viruses are usually enveloped and measure 100 to $180 \mathrm{~nm}$ in diameter (Hine et al. 1992; Nicolas et al. 1992; Renault et al. 2001a,b). No, or a reduced tegument is observed between the outer membrane and the capsid shell of enveloped particles.

In infected blood ark shell Scapharca[Anadara] broughtonii, observed viral particles were similar but slightly bigger than particles reported in oysters with nucleocapsids and enveloped extracellular viral particles measuring about 110 and $150 \mathrm{~nm}$ in diameter, respectively (Bai et al. 2016).

Oyster herpesvirus capsids are similar in overall appearance to those of other herpesviruses (Davison et al. 2005). The diameter estimated from cryo-electron microscopic images is approximately $116 \mathrm{~nm}$. The reconstruction of the oyster herpesvirus capsid revealed an icosahedral structure with a triangulation number of $T=16$ and allowed confirming that OsHV-1 was a herpesvirus, since this surface lattice geometry has been observed only with members of this family (Davison et al. 2005).

Abalone herpesvirus usually induces an acute disease with abalone dying within 1-2 days of demonstrating gross signs of the disease.

Several clinical signs have been reported in abalone infected with AbHV including hard foot' or tetany, irregular peripheral concave elevation of the foot; swollen and protruding mouth parts; eversion of the radula; minimal movement of the pedal muscle; excessive mucus production; absence of the marked extension of the foot shown in the righting reflex when healthy abalone are turned onto their backs and reduced pedal adhesion to the substrate (Ellard et al., 2009; Chang et al., 200, figure 6).

Gross signs including pustules and blisters are observed on the foot of infected animals and are considered as indicative of abalone viral ganglioneuritis (figure 7). 
Histologically, moribund abalones demonstrate ganglioneuritis - increased cellularity involving mainly haemocytes and glial cells, and cell necrosis. This increased hemocytic infiltration and necrosis is confined to neural tissues including cerebral, pleuropedal and buccal ganglia, branches of the pedal nerve and peripheral nerves (Chang et al. 2005; Ellard et al., 2009; Hooper et al., 2007, figure 8).

TEM examination of cerebral ganglions shows viral particles within the degenerated cells (figure 9). Viral particles are hexagonal, 90 to $100 \mathrm{~nm}$ in diameter (Chang et al. 2005). Some particles are empty while others contain a dense nucleoid. The morphology and size of the virus particles were similar to those documented previously in the oyster. 


\section{Diagnosis of viral infections in marine molluscs: diagnosing OsHV-1, a study case}

Diagnosis methods for OsHV-1 infections include conventional techniques (histology and transmission electron microscopy, TEM), and more recently molecular ones (polymerase chain reaction (PCR), real time PCR, DNA/RNA in situ hybridization, and nucleic acid sequence analysis. As all assays to grow OsHV-1 in culture cell lines failed, histology and TEM have been primarily used based on detection of cell lesions and direct visualization of the virus, respectively.

\section{Conventional techniques}

Histological examination of the animal on its own is not sufficient to identify a herpesvirus infection. As previously mentioned, Cowdry type A-like inclusions have never been reported following histological examination of infected Pacific oysters in France. Moreover, intranuclear inclusion bodies were not observed, although there was other cellular/nuclear pathology, in association with OsHV-1 infections in oysters in Mexico (Vásquez-Yeomans et al., 2010) or USA (California) (Friedman et al., 2005). Sections of tissue that include mantle, digestive gland, gills and adductor muscle should be sampled and fixed (using 10\% formaldehyde and processed using standard procedures, and stained with haematoxylin and eosin) for histological examination. The best preservative is Davidson's AFA, but 10\% buffered formalin or other standard histology fixatives are also acceptable. A positive result is the occurrence of cell abnormalities on tissue sections: fibroblastic-like cells exhibiting enlarged nuclei with perinuclear chromatin. Highly condensed nuclei are also reported in other cells interpreted as haemocytes. These cellular abnormalities are not associated with mass haemocyte infiltration. In susceptible host species, within the known range of OsHV-1, a positive result is presumptive evidence of OsHV-1 infection, but should be confirmed by 
species-specific PCR, in situ hybridisation (ISH) and/or DNA sequencing. The specificity of histology is very low, and sensitivity is good for moderate- to high-intensity infections, but low for low-intensity infections. Should perinuclear chromatin be observed by histology, transmission electron microscopy at the least should be undertaken to identify any virus particles present.

The presence of viral particles can be detected by TEM in infected animals. OsHV-1 replication mainly takes place in fibroblastic-like cells especially in mantle, labial palps, gills and digestive gland (Renault et al., 1994b; Renault et al., 1995). Capsids and nucleocapsids are observed in the nucleus of infected cells. Viral particles then pass through the nuclear membrane into the cytoplasm and enveloped particles are released at the cell surface. Intranuclear and cytoplasmic capsids present a variety of morphological types including electron lucent capsids, toroidal corecontaining capsids, and brick-shaped core-containing capsid. Viruses observed under the TEM should be described as e.g. herpesvirus-like until further investigations are done to provide further evidence of the identity of the virus. As different herpesviruses are morphologically similar, a virus should only be described as OsHV-1 if it had been shown to have identity with the latter virus using OsHV-1 specific primers or probes.

Specific antibodies have been also developed (Arzul et al., 2002)..

\section{Molecular techniques}

Extraction and sequencing of OsHV-1 DNA from purified particles infecting C. gigas larvae (Le Deuff and Renault 1999) rendered the development of molecular diagnosis tools possible. Molecular diagnostic assays such as conventional PCR, real time PCR, loop-mediated isothermal amplification, and DNA/RNA in situ hybridization assays have been developed to detect OsHV-1 (Barbosa-Solomieu et al., 2004; Burge and Friedman, 2012; Lipart and Renault, 2002; Oden et al., 2011; Pepin et al., 2008; Ren et al., 2013; Renault et al., 2000; 
Segarra et al., 2014a; Segarra et al., 2014b). This rise in molecular technologies has allowed improvements in diagnostic, epidemiological and research capabilities of aquatic animal health experts worldwide (Barbosa-Solomieu et al., 2004; Friedman et al., 2005; Garcia et al., 2011; Lynch et al., 2012; Renault and Arzul, 2001; Segarra et al., 2010; Webb et al., 2007). A real time reverse transcriptase PCR was recently developed to measure the expression of 39 virus genes in Pacific oyster tissues (Segarra et al., 2014a; Segarra et al., 2004b). In order to detect and localize viral RNA on histological sections, a specific in situ hybridization (ISH) assay was also developed (Corbeil et al., 2014). This technique provides information on the expression of three OsHV-1 genes in Pacific oyster tissues in relation to changes detected by histology and virus DNA detection by ISH and real time PCR.

\section{Conventional PCR and real time PCR}

Several PCR methods are available for the detection of OsHV-1 (Batista et al., 2007). This includes conventional PCRs using the primer sets C2/C4 and C2/C6 (Batista et al., 2007) as well as real time methods (Martenot et al., 2010; Pepin et al., 2008). Differences in sensitivity have been reported between different laboratories and different methods (Martenot et al., 2010). A protocol for quantification of OsHV-1 DNA in Pacific oysters based on a Sybr®Green real time PCR has been first developed (Pepin et al., 2008). Martenot et al. (2010) developed an alternative protocol based on TaqMan® chemistry. The quantification limits were 1000 and $18 \mathrm{UG} \mathrm{mg}^{-1}$ of tissues for the reference method and alternative protocols, respectively, and the latter protocol has a detection limit of $6 \mathrm{UG} \mathrm{mg}^{-1}$ of tissues.

Targeting different OsHV-1 genome areas is important in order to define more precisely viral types. Although ORF4 is an interesting candidate to describe diversity because virus polymorphism is reported in this area, ORF100 (DNA polymerase) appears as less polymorphic. 


\section{In situ Hybridization Detection}

The in situ hybridisation (ISH) procedure described here uses a digoxigenin (DIG)-labelled DNA probe to detect OsHV-1 in formalin-fixed, paraffin-embedded tissue (Arzul et al., 2002; Barbosa-Solomieu et al., 2004; Lipart and Renault, 2002). Thirty Pacific oysters, C. gigas, adults have been analysed using three different techniques: PCR, ISH and immunochemistry, in order to detect OsHV-1 in asymptomatic individuals (Arzul et al., 2002). PCR and ISH allowed detection of oyster OsHV-1 DNA in $93.3 \%$ and $86.6 \%$, respectively, of analysed oysters while polyclonal antibodies allowed detection of viral proteins in $76.6 \%$ of analysed adult oysters. Dig-labeled RNA probes and a specific in situ hybridization (HIS) assay were also recently developed (Corbeil et al., 2014).

\section{Sequence analysis and genotyping}

The search for association between virus genetic markers and clinical symptoms is of great interest and the characterization of the genetic variability of OsHV-1 specimens is an area of growing interest. Determination of nucleotide sequences of PCR-amplified virus DNA fragments has been used to characterize OsHV-1 specimens and virus variants have thus been described. Three different areas of the virus genome (ORF4, ORFs 35/36/37/38 and ORFs 42/43) have been selected in order to study the virus polymorphism by Renault et al. (2012) making it possible to define different sub-groups.

A genotyping method has recently been developed in order to characterize clinical OsHV-1 specimens by targeting a particular microsatellite locus located in the ORF4 area (Renault et al., 2014a). The microsatellite (H10) found in a noncoding region was selected since sequences were already available for this region demonstrating a high level of length polymorphism. The method was used to characterize 47 clinical OsHV-1 specimens by targeting this microsatellite. Sequencing and genotyping appeared to be equally useful to 
differentiate clinical OsHV-1 specimens. Genotyping based on virus microsatellites appears as a powerful tool to study OsHV-1 polymorphism and can offer a first level of discrimination between specimens in order to select best candidates for complete genome sequencing.

The routine use of molecular based diagnosis tools is hampered by major concerns. Not all regions of viral DNA are equally useful as targets for molecular detection. The assays often have not been thoroughly tested for inclusivity (detection of all types of the pathogen) or specificity (cross reaction with any other organism). The main concern is that molecular tools too often are developed from a few sequences without a good understanding of the overall sequence variability within the species. Moreover, molecular tools detect DNA and not necessarily a viable pathogen.

The presence of intracellular viral proteins, specific OsHV-1 messenger RNA, non-structural proteins and TEM demonstrating virions within cells constitute evidence for replication, but detection of viral presence by PCR alone does not. As moribund/dead bivalves from populations with mass mortality had high copy numbers of viral DNA, it may be possible in some cases to extrapolate those data to infer that OsHV-1 has replicated in animals (from known or new host species) with such high levels of viral DNA. However, rigorous evaluation and validation is required before those data could be used in that way.

It may be also possible to demonstrate viability by passage bioassay to a susceptible host with appropriate control animals. Detection of mortality or characteristic changes associated to detection of the virus is an important consideration in the assessment but not conclusive evidence of host susceptibility. The anatomic location of the pathogen is important also to exclude potential passive contamination of the host. This information can be obtained by techniques such as TEM, immuno-histochemistry or in situ hybridisation. 


\section{Epidemiology and ecology of viruses infecting marine molluscs}

Epidemiological data including factors influencing the dynamics of infection and life cycle are mostly available for members of the Herpesviridae family.

\section{Factors influencing the dynamics of infection}

Marine molluscs are generally bred in open environment and thus directly subject to the fluctuation of biotic and abiotic factors. Diseases occur when the balance between host, environment and pathogen factors is lost. Several works have investigated the potential impact of host, environment and husbandry practices on the dynamics of infection with viruses in molluscs.

- Host factors:

Although herpesviruses are generally host specific infecting one species, members of the Malacoherpesviridae characterized so far seem to be able to infect multiple mollusc species.

OsHV-1 infects a wide range of ostreidae, veneridae and pectinidae species.

Experimental trials showed that a similar genotype of OsHV-1 could induce an infection at larval stages in different bivalve species and that interspecies transmission could occur (Arzul et al. 2001a, 2001b, 2001c). Interestingly, the genotype $\mu$ Var seems more specific as mortality events related to its detection were only reported in oysters Crassostrea gigas, C. angulata (Batista et al. 2015) and Ostrea edulis (Lopez San Martin et al. 2016).

Like OsHV-1, AbHV does not present strict host specificity and has been detected in association with mortality of Haliotis laevigata, $H$. rubra, their hybrids as well as $H$. diversicolor (Chang et al. 2005; Hooper et al. 2007). 
All age and size classes of bivalves and gastropods are known to be affected by herpesviruses (Nicolas et al., 1992; Renault et al., 1995; Arzul et al., 2002; Garcia et al., 2011; Paul-Pont et al., 2013b; Whittington et al., 2015b, Chang et al. 2005, Hooper et al. 2007). However, in the case of OsHV-1, oysters less than 1 year of age are the most susceptible (Renault et al., 1995; Schikorski et al., 2011b; Garcia et al., 2011; Peeler et al. 2012; Whittington et al., 2015a). A negative correlation is observed between weight and mortality, and between individual mass and viral detection (Normand et al. 2014a). These results support the hypothesis that bigger oysters are more resistant to viral infection (Miossec et al., 2009) and are in line with studies showing that prior exposure to the virus has a protective effect. For example the origin of spat was identified as a major risk factor influencing the mortality in Ireland (Clegg et al. 2014). Spat originating from an endemic region regarding the variant $\mu$ Var displayed less mortality than spat from a free zone. Similarly, field test on non-previously exposed spat showed a rapid viral replication and a quick increase of mortality (Keeling et al. 2014).

If herpesviruses more generally induce mortality in young stages, adults might be infected and might act as reservoirs. However, in few examples, adults appear susceptible to the infection with herpesvirus. Mortality kinetics associated with the detection of the variant $\mu$ Var was atypical in Crassostrea angulata affecting adult oysters (Batista et al. 2015). Similarly, mass mortality associated with OsHV-1 was reported in broodstock in the blood ark shell Scapharca [Anadara] broughtonii (Bai et al. 2016). Notably, OsHV-1 infection of Chlamys farreri associated with mass mortalities was also found in adult individuals in China (Wang et al. 2002). These two last examples may indicate that the OsHV-1 virus variants found in China exhibit different host stage preference compared with those found in the other countries. 
Abalone herpesvirus has been associated with mortality of farmed and wild juveniles and adults. However, young stocks were more seriously affected by the virus outbreak than were older animals (Hooper et al. 2007).

Aquaculture selection programs have shown differential survival of $C$. gigas family lines exposed to the variant $\mu$ Var (Dégremont et al. 2011), establishing that there is an unidentified genetic component(s) affecting resistance to the disease. This selection might occur naturally contributing to enhance the resistance of natural population to the disease.

Correlation between ploidy and susceptibility to the infection with OsHV-1 is not clear. Although triploid stock might show higher levels of mortality associated with OsHV-1 than diploid (Peeler et al. 2012), there is often a risk of confounding effect such as the origin of the spat and or the period of introduction on the field.

- Environmental factors:

Marine molluscs are generally bred in open environment and thus directly subject to the fluctuation of biotic and abiotic factors. As poikilotherms they directly depend on temperature of the water explaining the predominant effect of this factor on the disease pattern and viral development. Other factors including salinity and phytoplankton have been investigated and are considered in this section.

A number of studies have highlighted the multifactorial nature of mortality events in young oysters (EFSA, 2010). Although environmental factors are not sufficient cause several authors have highlighted the potential role of increased water temperature in these oyster mortality events (Garcia et al. 2011 ; Le Deuff et al., 1996; Petton et al.,2013; Sauvage et al., 2009). Different temperature thresholds above which mortality outbreaks occur have been proposed: 
around $16{ }^{\circ} \mathrm{C}$ in both experimental (Petton et al., 2013) and field conditions (Pernet et al., 2012; Clegg et al. 2014; Renault et al. 2014b) in European waters and $24{ }^{\circ} \mathrm{C}$ in Australian waters (Paul-Pont et al. 2014). Additionally, the detection of OsHV-1 associated mortalities in France and USA occurs after a marked increase in mean daily seawater temperature $\left(+2-3{ }^{\circ} \mathrm{C}\right.$ over a couple of days) (Burge et al., 2006; Garcia et al., 2011; Jenkins et al. 2013; Sauvage et al., 2009 ; Paul-Pont et al., 2013b; Renault et al. 2014). Thermal challenge consisting in maintaining oysters at $21^{\circ} \mathrm{C}$ successfully triggered virus replication and increased associated mortality (Normand et al. 2014a) demonstrating the importance of temperature on the dynamic of infection with the virus.

In the bivalve species $S$. broughtonii, water temperature also appears as a key factor influencing OsHV-1 infection (Bai et al. 2016). Indeed, broodstocks mortality associated with OsHV-1 was only observed when the water temperatures had increased to $18^{\circ} \mathrm{C}$. On the other hand, no abnormal mortality was observed in juveniles of $S$. broughtonii cultivated at lower temperatures, which carried DNA of the same OsHV-1 variant.

Similarly, the temperature threshold associated with mass mortalities of $C$. farreri cultivated in the open sea in the 1990 s in China was $23-25^{\circ} \mathrm{C}$ (Wang et al. 2002).

In Australia the initial outbreak of abalone viral ganglioneuritis occurred in a farm during summer subsequently spread to wild populations which experienced mortality during all seasons (Hooper et al. 2007). In Chinese Taipei water temperature during the reported epizootic was $16-19^{\circ} \mathrm{C}$ (Chang et al. 2005). Experimental infections with Australian and Asian isolates are carried out in the temperature range $15-18^{\circ} \mathrm{C}$ and $17-20^{\circ} \mathrm{C}$, respectively (Chang et al. 2005 and Crane et al. 2009).

The possible effects of changes in other environmental factors such as salinity and dissolved oxygen are generally unknown. 
Although Pacific oysters can withstand salinity in the range of 10-42 ppt and salinity does not seem to play any important role in OSHV-1 expression (EFSA 2015; Paul-Pont et al. 2015), variation in salinity as well as extreme salinity values can significantly influence the immune systems of oysters and other bivalve molluscs, making them more susceptible to infection (Gagnaire et al.,2006; Hauton et al., 2000). Moreover, recent investigations have shown that salinity increases oyster mortality associated with OsHV-1 especially when oysters are not previously acclimatized and that low salinity (10) decreases OsHV-1 infectivity (Fuhrmann et al. 2016)

Few studies have investigated the potential effect of food quality on the development of the disease. In Thau lagoon a field study revealed that energetic condition of oysters, partly driven by variation in food quality, played a significant role in the spatial and temporal dynamics of disease mortality (Pernet et al. 2014). In particular, the relative contribution of diatoms to the diet of oysters was positively correlated with their energetic reserves, which in turn decreased the risk of disease mortality. These findings suggest that energetic status and food quality could have major implications for host-pathogen dynamics in marine ecosystems.

\section{- Husbandry practices:}

Some works have tested the potential influence of husbandry practices on the development and expression of infection with OsHV-1. Rearing in the intertidal regions and closed environments appeared to have a great influence on the mortality and the detection of the virus OsHV-1 (Garcia et al. 2011; Normand et al. 2014a). More particularly, time spent in water could have an impact on the risk to be exposed and then infected with the virus (Peeler et al. 2012) Manual handling of spat was also found associated with higher levels of mortality compared with mechanical handing (80 versus 50\%) (Peeler et al. 2012). Cultivation structure 
(floating baskets, hanging baskets or trays) or height did not appear influencing the long-term survival of spat, but did affect their growth (Whittington et al. 2015b).

In abalone farms in Australia, the role of stress factors including high densities, spawning period and water temperature was highly suspected as contributing factors to the high mortality rates (Hooper et al. 2007).

\section{Infection cycle}

Viruses are obligatory intracellular micro-organisms. However they have to be transferred from infected animals to non-infected ones to survive. Different routes of transmission might be used by viruses to infect new hosts. Among the most studied viruses infecting marine molluscs, seawater appears as a major medium in the horizontal transmission. However, other ways might be followed by viruses as highlighted in the following sections.

- Seawater: a medium in the horizontal transmission

Experimental infection models have been developed and allowed better understanding of the transmission routes and the infection cycles of the herpesviruses OsHV-1 and AbHV.

Transmission experiments demonstrated pathogenicity of OsHV-1 at larval and juvenile stages (Le Deuff et al. 1994; Schikorski et al. 2011a) with an incubation period of 3 days and mortality rapidly rising up to $100 \%$.

Cohabitation of oysters considered as not infected with infected oysters in $1 \mu \mathrm{m}$ filtered seawater was shown to be an effective method for transmitting OsHV-1 and inducing clinical disease, with viral DNA detected in tank water at concentrations of between 101-103 DNA copies per $\mu \mathrm{L}$ over a sampling period of 7 days (Schikorski et al., 2011a). In these experiments, viral DNA could be detected in challenged oysters as soon as $6 \mathrm{~h}$ of cohabitation with infected oysters demonstrating that seawater acts as a medium in the horizontal 
transmission of OsHV-1 between infected spat and and juvenile oysters considered as noninfected.

Viral survival in seawater is not known. However, Vigneron et al. (2004) monitored viral DNA detection in different media and at different temperature by PCR. Although detection of DNA does not allow concluding about viral survival it is worthwhile to note that OsHV-1 DNA from infected larvae samples could be amplified after up to $22 \mathrm{~d}$ of incubation in natural sea water at $4^{\circ} \mathrm{C}$.

Horizontal transmission via seawater has been demonstrated experimentally for the abalone herpesvirus (Chang et al. 2005; Crane et al. 2009; Corbeil et al. 2012a). Exposing healthy abalone to diseased abalone or to water that was previously inhabited by diseased abalone induced $100 \%$ of mortality after a preclinical period of 1-2 days.

AbHV stability was determined at different temperatures by holding virus at 4,15 , or $25^{\circ} \mathrm{C}$ for 1, 5, and 12 days prior to immersion challenge of "naïve" abalone (Corbeil et al. 2012b). Results of this experiment indicated that when held for 1 day in sea water at $4{ }^{\circ} \mathrm{C}$ and $15{ }^{\circ} \mathrm{C}$ the virus remained infectious and highly pathogenic. In addition, the virus retained partial infectivity after 5 days held at $4{ }^{\circ} \mathrm{C}$.

\section{- Aquatic mechanical or biological vectors}

Several studies of natural transmission events suggested that an aquatic mechanical vector or particle can be involved in the transmission of the virus (Paul-Pont et al., 2013a; Evans et al. 2014; Whittington et al., 2015b). More particularly, the spatial distribution of oyster mortalities observed in Georges River estuary in Australia was similar to that typically seen in planktonic aggregations and communities and it was hypothesized that the virus may be attached to such particles (Paul-Pont et al., 2013a). 
Evans et al. (2014) suggested that OsHV-1 may be present in seawater in a range of forms including free virus, flocculated or aggregated virus, virus adsorbed to particles the same size as plant or animal cells (or larger), or various viral components at differing stages of the replication process, including free viral DNA.

Interestingly, herpes-like viral particles have previously been observed in fungoid protist and fungi (Kazama and Schornstein 1972, 1973; Renault et al. 2003) suggesting that fungi or marine heterotrophic protists may be involved in the transmission of marine herpesviruses.

These different reports suggest that the virus may be attached or even may infect planktonic organisms. Herpesviruses are assumed to be fragile outside their hosts. The transfer through planktonic organisms might thus protect viruses during their life outside their mollusc hosts.

- Viral reservoirs

Vertebrate herpesviruses generally cause disease in young individuals and then persist under persistent/latent forms for the lifetime of their hosts. Although there is no demonstration of persistence/latency for mollusc herpesviruses, some results suggest that OsHV-1 can persist in adult oysters. Indeed, OsHV-1 DNA and proteins have been detected in asymptomatic Crassostrea gigas adults (Arzul et al. 2002, Barbosa-Solomieu et al. 2004, 2005, Dégremont et al., 2013, Paul-Pont et al. 2014, Segarra et al., 2014b). In a survey performed in New South Wales, Australia, infection prevalence and DNA viral loads decreased over time confirming that surviving oysters are able to eliminate viral DNA from their tissues (Paul-Pont et al., 2013b;). However it is unclear how long those sub-clinically infected oysters constitute a reservoir for OsHV-1 and what their role is in subsequent infections. 
In addition, the detection of low level of viral DNA in other bivalve species including mussels (EFSA, 2015) raises the question of the potential role of these species as reservoirs for the virus.

The detection of viral DNA and protein in adult oysters and more particularly in the gonad (Arzul et al. 2002) questions the ability of the virus to be transmitted vertically. Indeed, adult oysters may play the role of carriers and reservoirs of the virus promoting virus transmission from adults to larvae (Le Deuff et al. 1996, Arzul et al. 2002). In addition, a study carried out on successive generations of $C$. gigas suggested that the infective status of the parents might have an influence on both the infection and the survival rates of the progeny (BarbosaSolomieu et al. 2004). These results strengthen but do not confirm the hypothesis of vertical transmission. 


\section{Interactions between marine viruses and molluscs}

The host-pathogen interactions between marine viruses and molluscs are poorly characterized; most studies are based on two model bivalve molluscs, Crassostrea gigas and Chlamys farreri and on the gastropods Haliotis spp. These interaction studies have focused on genomics, transcriptomics and proteomics, there are fewer studies pertaining to cellular interactions. This can be explained by the absence of cell lines in marine molluscs, however, recent progress has been made with the development of stem cells in the cupped oysters $C$. gigas (Jemaà et al., 2014). With regards to the ostreid herpesvirus 1 (OsHV-1) and the abalone herpesvirus (AbHV), it was shown that they do not replicate in the single embryonic cell line of the gastropod mollusc Bionphalaria gabralata (Renault, personal communication).

OsHV-1 and Crassostrea gigas

Studies involving OsHV-1 and Crassostrea gigas mainly focused on the characterization of the transcriptional host response upon virus infection, and on the identification of antiviral compounds. Many studies used an heterologous model involving herpes simplex virus-1 (HSV-1) and kidney cells from African green monkey (Vero) for identifying antiviral compounds in tissue homogenates from commercially important bivalve species (CarrielGomes et al, 2006 ;. Green et al, 2014c;. Olicard et al, 2005a, b;. Segarra et al, 2014a;. Zeng et al., 2008). Olicard et al (2005 a and b) demonstrated first an antiviral activity in the hemolymph of adult Pacific oysters related to a the detection of a peptide. Another study showed that an anti-HSV-1 activity is related to a glycoprotein containing copper, called cavortin. This protein is predominant in the plasma of the hemolymph. Green et al. (2014b) showed that this protein has antiviral properties and helps fight against virus replication. 
Renault et al. (2011) reported the first study identifying genes differentially expressed between hemocytes in contact with OsHV-1 and control ones. This study also allowed the complete characterization of several genes of interest, such as IFI 44, MYD88, Glypican and Laccase genes. Following this approach several genomic and proteomic studies, investigating host-pathogen interactions have been undertaken (Corporeau et al, 2014;. Du et al, 2013 ; Huvet Fleury, 2012; Green \& Montagnani, 2013; Jouaux et al, 2013; Normand et al, 2014b; Segarra et al, 2014a, b, c; Tamayo et al, 2014, Moreau et al, 2015). These studies mainly focus on the response of infected oysters under different conditions, highlighting the possible involvement of certain genes in response to infection. Segarra et al. (2014a, b and c) performed a study on double transcriptomics approach (oyster/virus), this was the first studies on the kinetics of viral genes expression in parallel with oyster gene expression.

To further study interactions between the virus and its host, some authors studied the expression of viral and oyster genes in oyster families presenting contrasted resistance to OsHV-1 infection (Segarra et al, 2014b). Moreover, the availability of the Pacific oyster full genome sequence opens up new approaches to unravel virus and mollusc transcriptomes (Rosani et al, 2014; $\mathrm{He}$ et al, 2015). All these studies were able to show the involvement of immune genes in the antiviral response, these genes are involved in processes such as an interferon-like pathway, RNA interference, programmed cell death, and autophagy. Results suggested that antiviral responses in a bivalve mollusc present some similarity with antiviral responses in higher organisms.

An original approach using a two-dimensional electrophoresis (2-DE) proteomic- (Corporeau et al. 2014) brought new information at a proteomics level. OsHV-1 challenged oysters exhibited an increased glycolysis and VDAC accumulation, which reflect a "Warburg effect" as initially reported in cancer cells and more recently in shrimp infected with virus (Corporeau et al, 2014). A recent follow-up study showed that the VDAC2 gene is involved in 
apoptosis modulation and host defense in molluscs. This study was the first using a RNA interference approach to show gene involvement in response to pathogen infection ( $\mathrm{Li}$ et al., 2016).

Due to the absence of IFN encoded in their genomes, invertebrates were thought to lack the interferon (IFN) pathway. However, Green et al. (2015b) have explored the role of the viperin in oysters. Viperin, an antiviral protein, is often described in different organisms. In the Pacific oyster genome, ISGs are found including a viperin-like protein. These authors showed that oyster viperon co-localizes with caveolin-1 and inhibits dengue virus replication in a heterologous model. In a second set of experiments, they provided evidence that the hemolymph from poly (I:C)-injected oysters contains a heat-stable protease susceptible factor that induces hemocyte transcription of viperin mRNA in conjunction with up-regulation of ISGs. Collectively, these results support the concept that oysters have antiviral systems that shows similarity with the vertebrate IFN pathway (Green et al., 2015a).

Apoptosis is a form of program cell death (PCD). PCD is a cellular response to prevent viral replication and protein synthesis in virus-infected cells, and viral spread to uninfected cells. The apoptosis pathway appears highly conserved in the $C$. gigas based on its genome sequence. Moreover the number of inhibitor of apoptosis proteins (IAPs) is considerable (49 IAPs) (Zhang et al., 2011). OsHV-1 genome encodes multiple inhibitors of apoptosis (Davison et al., 2005) implying that apoptosis may represent an important antiviral response in molluscs. Renault et al. (1994b, 2001a and b) reported first apoptotic cells in infected oysters based on transmission electron microscopy examination. Segarra et al (2014b) demonstrated differential mRNA expression of an IAP gene in oyster spat showing different levels of susceptibility to the viral infection. They reported a positive correlation between the 
level of IAP transcripts and the amounts of viral DNA. Segarra et al (2014c) showed also that the IAP gene was up-regulated during viral infection compared to controls in adult oysters. Over-expression of IAP could be a reaction to the apoptotic process induced by OsHV-1 infection. The capacity of adult oysters to inhibit and control the apoptotic process could be essential for survival. Green et al. (2015) investigated the role of the apoptosis during an OsHV-1 infection in C. gigas. They have shown that the extrinsic apoptosis pathway related to Tumor Necrosis Factor (TNF) was induced in response to the viral infection, but they failed to observe evidence of apoptosis using a combination of biochemical and molecular assays. IAPs encoded by OsHV-1 were highly expressed during the acute stage of infection and may explain why they didn't observe evidence of apoptosis. However, C.gigas must have an alternative mechanism to apoptosis for clearing OsHV-1 from infected gill cells as they observed a reduction in viral DNA between 27 and 54 h post-infection (Green et al., 2015). Martenot et al (2016) demonstrated the detection of a viral putative apoptosis inhibitor (ORF87) in cell nuclei in connective tissues of several organs/tissues in infected oyster based on the use of specific polyclonal antibodies. Protein encoded by ORF 87 contains a BIR domain which might inhibit apoptosis by acting as direct inhibitors of caspases.

Autophagy is another form of programmed cell death. Genes involved in autophagy pathway appear highly conserved. An original study conducted by Moreau et al. (2015) showed that $A T G$ genes are present in the Pacific oyster genome. Oyster $A T G$ genes appear to be closer to human genes than those found in Drosophila or C. elegans. The authors also showed that the autophagy pathway plays a role in protecting Pacific oysters from OsHV-1 infection, and autophagy stimulation is associated with higher oyster survival. Interestingly, they observed that Pacific oyster families, which have low or high susceptibility to OsHV-1 infections, did not modulate autophagy with the same amplitude. This study showed for the first time a 
protective role of autophagy against OsHV-1 infection in Pacific oysters in experimental conditions and suggested a potential strategy to fight against these infections by selecting animals that have high autophagy induction potential.

$A V N V$ and Chlamys farreri

There are few studies describing Acute Viral Necrobiotic Virus (AVNV) and Zhikong Scallop Chlamys farreri_interactions. However, those available have focused on the cellular and molecular responses of the scallop upon AVNV infection (Chen et al, 2011, 2013, 2014; 2015; Tang et al, 2010;. Xing et al, 2008).

One study described the scallop hemocyte enzyme activities including acid phosphatase (ACP), alkaline phosphatase (ALP), superoxide dismutase (SOD), myeloperoxidase (MPO), phenoloxidase (PO), peroxidase (POD) and catalase (CAT). Xing et al (2008) showed that after infection MPO and PO increased, then decreased gradually and remained steady. ALP activity was not detected. The authors suggested that both enzymes could potentially be used as useful indicators for evaluating the physiological status of scallop C. farreri (Xing et al, 2008). In order to complement this study, Tang et al (2010) studied the physiological and immune responses of $C$. farreri to viral infection monitoring oxygen consumption rate, ammonium-nitrogen excretion rate, hemocyte copper, zinc superoxide dismutase gene expression, and plasma superoxide dismutase activity as well as alkaline phosphatase activity

. Real-time PCR revealed that the hemocyte cytosol $\mathrm{Cu}, \mathrm{ZnSOD}$ gene expression was upregulated followed by recovery. In contrast, the plasma SOD activity increased consistently following virus injection. Moreover, plasma AKP activity first decreased and then increased gradually to reach the highest level $24 \mathrm{~h}$ post virus injection. Scallops challenged with AVNV 
at $17^{\circ} \mathrm{C}$ neither developed notable disease nor showed obvious responses that could be associated with viral infection.

Proteomic and transcriptomic studies have also been performed using C. farreri challenged with AVNV (Chen et al, 2011, 2013, 2014; 2015) including a comparative analysis of hemocyte differentially expressed proteins. A total of 42 spots were successfully identified by MALDI-TOF-MS with online NCBI and EST databases. All identified proteins could be classified into eight categories, i.e. cytoskeleton proteins, proteins involved in metabolism, calcium homeostasis related proteins, chaperones, proteins involved in immunity, proteins involved in transcriptional regulation, proteins related to signal transduction, and ungrouped proteins.

Chen et al (2013) performed a comparative analysis of differentially expressed genes in hemocytes of $C$. farreri in response to AVNV infection using suppression subtractive hybridization (SSH). This technique provided new information on differentially expressed genes as a total of 168 expressed sequence tags (ESTs) were identified. Some of these ESTs presented coding sequences related to proteins such as QM-like protein, Duox and TCTP (Translationally controlled tumor protein). These proteins are tumor suppressors, ubiquitously expressed and have functions of slowing down cell division, repairing DNA and regulating apoptosis (Chen et al, 2013). The (Chlamys farreri QM) CfQM has been fully characterized by RACE-PCR after a viral challenge, the relative mRNA expression of CfQM sharply increased at $6 \mathrm{~h}$ post-infection (hpi) and then normalized at $48 \mathrm{hpi}$ (Chen et al., 2015).

MiRNAs are molecules known to play an important role in the development of organisms as well as being involved in several other biological processes. Chen et al. (2014) constructed two small RNA libraries from hemocytes collected in healthy individuals and AVNV infected ones. After sequencing and data analysis, they identified that miRNAs may target 177 genes 
involved in a broad range of biological processes including immune defense and stress response. This study was the first to use deep sequencing to characterize $C$. farreri miRNAs and miRNA expression profiles in response to a virus infection in mollusc

\section{AbHV and Haliotis sp.}

The last model presented in this section is the abalone and AbHV. Only one study has been done on this model from an immunological standpoint. It involves the characterization of hybrid abalone (Haliotis laevigata $\times$ Haliotis rubra) immune parameters following AbHV challenge (Dang et al., 2013). Measurements performed included total hemocyte count (THC), detection of superoxide anion (SO) and antiviral activity against herpes simplex virus

1 (HSV-1). These were examined in apparently healthy (sub-clinical) and moribund abalone after challenge. THC and SO level were found to be negatively correlated with the presence of AbHV in abalone. The anti-HSV-1 activity of abalone plasma did not increase above baseline levels in response to experimental infection with AbHV (Dang et al., 2013). However, abalone hemocyanin inhibited HSV-1 infection of Vero cells, presumably by blocking viral entry (Dang et al., 2011; Zanjani et al., 2014).

In summary, most information on the interactions between marine viruses and their mollusc hosts has been obtained from the $C$. gigas and OsHV-1 model and to a lesser extent from other models. In addition, many studies on interactions focused on the transcriptome aspect and fewer studies covered the cellular aspect, this being due to the lack of marine bivalve cell lines. However, new high-throughput sequencing technologies have begun to provide essential transcriptomics data allowing understanding of these interactions. 
It remains nevertheless necessary to study the mechanisms of resistance and tolerance of bivalve molluscs upon viral infection in order to identify the effectors responsible for existing resistance or tolerance. Due to lack of information on virus virulence mechanisms, functional genomics (Gene silencing) approaches must be undertaken to shed more light on the role of pathogens and hosts genes in interactions between viruses and molluscs. 


\section{Control and Management of viral diseases}

Control and management of viral diseases in molluscs mainly involves active surveillance, implementation of effective bio-security protocols and other innovations such as mollusc breeding programs targeting production of resistant animals (Renault, 2009; Renault, 2012; Paul-Pont et al., 2013 b). The availability and implementation of control and management strategies are dependent on environmental conditions, aquaculture set up, species cultivated and viruses that infect these species. This section will summarize some strategies and principles important to limit the impact of viruses, more specifically herpesviruses, on mollusc culture.

\section{Bio-security}

Avoiding the introduction of pathogens within aquaculture facilities or regions where mollusc are cultivated is the first management step to maintain healthy animal production. Programs of periodic surveillance testing for disease agents, and exclusion performed prior to translocation/export to other areas allow control of disease spread and reduction of disease prevalence in aquaculture facilities and wild stocks. However, when wild populations provide reservoirs of infection, prevention of disease spread is practically impossible. In order to maintain international trade, zoning and compartmentalization procedures are recommended to countries to define subpopulations of distinct aquatic animal health status (World Organisation for Animal Health, 2015).

Preventing spread of viruses within aquaculture facilities and the greater environment is crucial to maintain healthy mollusc crops, broodstock and wild populations. Disinfection of facilities and equipment, and use of bio-secure modes of transportation are essential components of a comprehensive biosecurity program. Such bio-security measures may be 
used to eradicate or exclude specific diseases from aquaculture establishments, and should be an integral part of routine sanitary measures to reduce disease incidence (World Organisation for Animal Health, 2014). Physico-chemical conditions such as temperature, $\mathrm{pH}$, exposure time, presence of organic matter, are all factors that influence the ability to disinfection of water, tanks, ponds and equipment. Some examples of disinfection measures and their virucidal efficacy on herpesviruses in aquaculture facilities are well described by Corbeil et al. (2012a) and Hick et al. (2016).

\section{Environmental controls}

The ostreid herpesvirus-1 (OsHV-1) and the abalone herpesvirus (AbHV) have had devastating impacts on the Pacific oyster and abalone industries. Implementing strategies that aim at using environmental factors (e.g. height of bags vs tide, food availability, water temperature) that influence disease onset and/or severity may help mitigate the impact of these pathogens. In the case of OsHV-1 exclusion from entry into onshore rearing hatcheries is difficult to implement as the virus is highly prevalent in Europe and often sub-clinical in wild oyster stocks (Normand et al., 2014a; Arzul et al., 2002; Renault at al, 2014). Researchers warn that oyster populations considered free of virus (but more accurately, below the detection limit of diagnostic tests) that appear suitable as broodstock could spread disease once external stimuli trigger viral proliferation (Normand et al., 2014a, Burge et al., 2006; Renault et al, 2014). Indeed, it has been shown that an increase in water temperature (e.g. up to $21^{\circ} \mathrm{C}$ ) and/or food availability triggers OsHV-1 reactivation of latent infection.

Research has shown that the Pacific oyster relies on a cellular response measured by antiviral gene expression in circulating hemocytes to control OsHV-1 replication. Furthermore, this antiviral response is dependent on water temperature and host development where the size of 
oysters affects their susceptibility to infection by OsHV-1 and disease; the smaller oysters are the more susceptible they are (Garcia et al, 2011; Green et al., 2014b; Normand et al., 2014a). Longer exposure to warmer water temperatures reduces AbHV viability (Corbeil et al., 2012a), and, similarly, OsHV-1 stability in sea water is modulated by temperature; elevated temperature is detrimental to virus survival (Martenot et al., 2015). Therefore, setting appropriate water temperature, the size and oyster density would most likely limit the contagion and outbreak intensity. It would be difficult to significantly adjust the sea water temperature in a hatchery setting with flow through due the huge thermal mass of water, however, such an option could be available in a recirculation system. Temperature could be adjusted depending on the mollusc species cultivated and the viral agent affecting it.

Recently, Whittington et al. (2015b) have evaluated a new management strategy to protect Pacific oyster larvae and spat in hatchery production. Their findings indicate that OsHV-1 particles spread mainly by binding to particulate matter, and, sedimentation and filtration of estuarine water supply enable safe production of spat in infected estuaries. Such strategy would allow farmers to hold spat in land-based facilities during the seasonal window of OsHV-1 infection. Further study on management practice in grow out facilities showed that survival of 12-month-old Pacific oysters could be increased in OsHV-1 prevalent estuaries by raising the growing height of the cultivation structure. The underlying factors for this effect are not clear but could involve a lower exposure to a lethal dose of viral particles due to diminution of immersion time and feeding activity (Paul-Pont et al., 2013b).

\section{Trangenics}

Many studies on oyster gene expression have shown that they can recognize virus-associated molecular patterns to induce a systemic transcriptional response that is capable of controlling OsHV-1 infection and replication (Green et al., 2015; Green et al., 2014a, b; Green and 
Montagnani, 2013; Renault et al., 2012, Segarra et al, b and c). Molluscs expressing small interference RNA molecules targeting specific viruses could be of great value to reduce the impact of herpesviruses such as OsHV-1 or AbHV as they would be inherently resistant to the pathogen.

\section{Breeding programs}

Studies of Pacific oysters infected with OsHV-1 have clearly shown that antiviral resistance is enhanced by selective breeding (Dégremont 2013; Dégremont et al., 2013, 2015a, b; Green et al., 2015; Ségarra et al., 2014b). In addition, selected OsHV-1 resistant oysters had lower mortality, lower prevalence of infection, and consequently, lower ability to transmit the disease than unselected oysters (Dégremont et al., 2013).

Interestingly, Dégremont et al. (2015b) highlighted the fact that appropriate culturing practices need to be implemented with OsHV-1 resistant oysters in order to increase growth and profitability. In France selective breeding programs succeeded in increasing OsHV-1 resistance across a wide area where the disease is enzootic (Mediterranean Sea to the English Channel) and was shown to be an asset in the control of disease outbreaks in oysters (Garcia et al., 2011; Dégremont et al., 2015c).

Although genetic traits of virus resistance in gastropods have not been extensively investigated, some Australian greenlip abalone family lines showed a slight increase in resistance to infection by the abalone herpesvirus (Corbeil et al., 2013). 


\section{Closing thoughts}

Our current knowledge on viruses affecting marine molluscs is mostly restricted to viruses affecting farmed species such as oysters Crassostrea gigas, Abalone Haliotis diversicolor supertexta or the scallop Chlamys farreri. Indeed, farmed animals are followed more carefully than wild populations and rearing conditions probably enhance their transmission and thus their detection. However, considering the development of high throughputs sequencing and results of studies investigating viral diversity in ocean, we can assume that many more mollusc viruses await discovery.

In the recent years, the sequencing of the total genome of some of these mollusc viruses has allowed exploring the intra species diversity and designing more relevant diagnostic tools. The comparison between these genomes allows now questioning their evolution and the co evolution with their mollusc hosts.

The lack of marine mollusc cell culture not only restricts virus isolation capacities and subsequent characterization works but also limits investigations on host-virus interactions. Nevertheless, these last years, many studies have been carried out to better understand the response of the oyster Crassostrea gigas to an infection with OsHV-1. The publication of the genome of Crassostrea gigas (Zhang et al. 2012), the development of resistant families and experimental challenge protocols have definitely facilitated investigations on the oyster-virus interactions. These works have contributed to improve our knowledge of resistant mechanisms developed by the oyster and more widely of the antiviral immune responses in molluscs. 
In a production which generally takes place in open areas, eradication programme, the use of treatment or vaccine are generally not conceivable. Preventing pathogen introduction is thus a priority. However, in an infected population or farm, the goal is likely to better live with the virus for example by using stock management measures that do not favour pathogen multiplication and by using animals showing better survival against an infection.

In that context, identification of genetic makers associated with a higher resistance against an infection could be of interest for the development of marker assisted selection programme.

Factors triggering pathogen development and the life cycle and status of the viruses outside their mollusc hosts still need further investigations. 


\section{Acknowledgments}

We gratefully thank B. Chollet (LGPMM, Ifremer), L. Williams and A. Hyatt (AAHL, CSIRO) for providing some of the figures. 


\section{References}

Alderman D.J., Gras P., 1969, "Gill disease” of Portuguese oysters. Nature 224, 616-617.

Arzul, I., Renault, T., Lipart, C., 2001a. Experimental herpes-like viral infections in marine bivalves: demonstration of interspecies transmission. Dis. Aquat. Org. 46, 1-6.

Arzul, I., Nicolas, J.-L., Davison, A.J., Renault, T., 2001b. French scallops: a new host for ostreid herpesvirus-1. Virology 290, 342-349.

Arzul, I., Renault, T., Lipart, C., Davison, A.J., 2001c. Evidence for interspecies transmission of oyster herpesvirus in marines bivalves. J. Gen. Virol. 82, 865-870.

Arzul I., Renault T., Thébault A., Gérard A. 2002. Detection of oyster herpesvirus DNA and proteins in asymptomatic Crassostrea gigas adults. Virus Res 84: 151-160.

Bai, C., Gao, W., Wang, C., Yu, T., Zhang, T., Qiu, Z., Wang, Q., Huang, J. (2016). Identification and characterization of ostreidherpesvirus 1 associated with massive mortalities of Scapharca broughtonii broodstocks in China. Dis Aquat Org 118:65-75. doi: 10.3354/dao02958

Barbosa-Solomieu V., Degremont L., Vazquez-Juarez R., Ascencio-Valle F., Boudry P. \& Renault T. (2005). Ostreid herpesvirus 1 (OsHV-1) detection among three successive generations of Pacific oysters (Crassostrea gigas). Virus Res., 107, 47-56

Barbosa-Solomieu V., Miossec L., Vazquez-Juarez R., Ascencio-Valle F. \& Renault T. (2004). Diagnosis of Ostreid herpesvirus 1 in fixed paraffin-embedded archival samples using PCR and in situ hybridisation. J. Virol. Methods, 119, 65-72

Batista, F.M., Arzul, I., Pepin, J.F. et al. 2007. Detection of ostreid herpesvirus-1 DNA in bivalve molluscs: a critical review. Journal of Viroogical Methods 139(1):1-11.

Batista F, López-Sanmartín M., Grade A., Morgado I., Valente M., Navas J.-I., Power D.-M., F. Ruano. 2015. Sequence variation in ostreid herpesvirus 1 microvar isolates detected in dying and asymptomatic Crassostrea angulata adults in the Iberian Peninsula: Insights into viral origin and spread, Aquaculture, 435: 43-51.

Bower, S.M. (2010): Synopsis of Infectious Diseases and Parasites of Commercially Exploited Shellfish. http://www.dfo-mpo.gc.ca/science/aah-saa/diseases-maladies/indexeng.html 
Burge C.A., Griffin F.J., Friedman C.S. 2006. Mortality and herpesvirus infections of the Pacific oyster Crassostrea gigas in Tomales Bay, California, USA. Dis Aquat Org 72: 31-43.

Burge, C., Judah, L.R., Conquest, L.L., Griffin, F.J., Cheney, D.P., Suhrbier, A., Vadopalas, B., Olin, P.G., Renault, T., Friedman, C.S. (2007). Summer seed mortality of the Pacific oyster, Crassostrea gigas Thunberg grown in Tomales Bay, California, USA: the influence of oyster stock, planting time, pathogens, and environmental stressors. J. Shellfish Res. 26:163172.

Burge, C., Friedman, C.S. 2012. Quantifying ostreid herpesvirus (OsHV-1) genome copies and expression during transmission. Microbial Ecology 63:596-604.

Brum JR, Ignacio-Espinoza JC, Roux S, Doulcier G, Acinas SG, Alberti A, Chaffron S, Cruaud C, de Vargas C, Gasol JM, Gorsky G, Gregory AC, Guidi L, Hingamp P, Iudicone D, Not F, Ogata H, Pesant S, Poulos BT, Schwenck SM, Speich S, Dimier C, Kandels-Lewis S, Picheral M, Searson S; Tara Oceans Coordinators, Bork P, Bowler C, Sunagawa S, Wincker P, Karsenti E, Sullivan MB. 2015. Ocean plankton. Patterns and ecological drivers of ocean viral communities.Science. 2015 May 22;348(6237):1261498. doi: 10.1126/science. 1261498.

Carriel-Gomes M.C., Kratz J.M., Muller V.D.M., Barardi C.R.M., Simoes C.M.O. 2006. Evaluation of antiviral activity in the hemolymph from oysters Crassostrea rhizophorae Crassostreea gigas Aquat Living Resour 19 189-193

Chang, P. H., Kuo, S. T., Lai, S. H., Yang, H. S., Ting, Y. Y., Hsu, C. L.,. Chen, H. C. 2005. Herpes-like virus infection causing mortality of cultured abalone Haliotis diversicolor supertexta in Taiwan. Dis. Aqua. Org. 65:23-27.

Chen G., Zhang C., Li C., Wang C., Xu Z., Yan P. 2011. Haemocyte protein expression profiling of scallop Chlamys farreri response to acute viral necrosis virus (AVNV) infection Dev Comp Immunol 35 1135-1145.

Chen G., Wang C., Zhang C., Wang Y., Xu Z., Wang C. 2013. A preliminary study of differentially expressed genes of the scallop Chlamys farreri against acute viral necrobiotic virus (AVNV) Fish Shellfish Immunol 34 1619-1627.

Chen G., Zhang C., Jiang F., Wang Y., Xu Z., Wang C. 2014. Bioinformatics analysis of hemocyte miRNAs of scallop Chlamys farreri against acute viral necrobiotic virus (AVNV) Fish Shellfish Immunol 37 75-86 
Chen G., Zhang C., Wang Y., Wang Y., Guo C., Wang C. (2015) Molecular characterization and immune response expression of the QM gene from the scallop Chlamys farreri.Fish Shellfish Immunol. 2015 Aug;45(2):543-50. doi: 10.1016/j.fsi.2015.05.011. Epub 2015 May 14.

Cheslett D, Mc Kiernan F, Hickey C, Collins E (2009) Viral gametocytic hypertrophy of the Pacific oyster Crassostrea gigas in Ireland. Dis Aquat Org 83:181-185

Choi DL, Lee NS, Choi HJ, Park MA, McGladdery SE, Park MS (2004) Viral gametocytic hypertrophy caused by a papova-like virus infection in the pacific oyster Crassostrea gigas in Korea. Dis Aquat Org 59:205-209

Chou, HY, Li, HJ, Lo, CF. (1994). Pathogenicity of a birnavirus to hard clam (Meretrix lusoria) and effect of temperature stress on its virulence. Fish Pathol. 29(3):171-175.

Chou, HY., Chang, SJ., Lee, HY., Chiou, YC. (1998). Preliminary evidence for the effect of heavy metal cations on the susceptibility of hard clam (Meretrix lusoria) to clam birnavirus infection. Fish Pathol. 33:213-219.

Clegg T.A., Morrissey T., Geoghegan F., Martin S.W., Lyons K., Ashe S., S J. More. 2014 Risk factors associated with increased mortality of farmed Pacific oysters in Ireland during 2011. Preventive Veterinary Medicine, 113(2):257-267.

Cohen, J. I., Nguyen, H. (1998). Varicella-Zoster virus ORF61 deletion mutants replicate in cell culture, but a mutant with stop codons in ORF61 reverts to wild-type virus. Virology 246:306-316.

Comps M., 1969, Observations relatives à l'affection branchiale des huîtres portugaises (Crassostrea angulata Lmk). Rev. Trav. Inst. Pêches Marit. 33, 151-160.

Comps M., 1970, La maladie des branchies chez les huîtres du genre Crassostrea. Caractéristiques et évolution des altérations, processus de cicatrisation. Rev. Trav. Inst. Pêches Marit. 34, 24-43.

Comps M., 1978, Evolution des recherches et études récentes en pathologie des huîtres. Oceanol. Acta 1, 255-262.

Comps M., 1980, Les infections virales associées aux épizooties des huîtres du genre Crassostrea. International Council for the Exploration of the Sea. Spec. Meeting on Diseases of Commercially Important Marine Fish and Shellfish, Copenhagen No. 6. 
Comps M., Bonami J.R., 1977, Infection virale associée à des mortalités chez l'huître Crassostrea angulata Th. C. R. Acad. Sci. D 285, 1139-1140.

Comps M., Duthoit J.L., 1979, Infections virales chez les huîtres Crassostrea angulata (Lmk) et C. gigas (Th.). Haliotis 8 (1977), 301-308.

Comps M, Cochennec N (1993) A herpes-like virus from the European oyster Ostrea edulis L. J Invertebr Pathol 62: 201-203

Comps M., Bonami J.R., Vago C., Campillo A., 1976, Une virose de l'huître portugaise (Crassostrea angulata Lmk). C. R. Hebd. Séanc. Acad. Sci. D 282, 1991-1993.

Cook ,P.A.(2014) The Worldwide Abalone Industry. Modern Economy,5, 1181-1186. http://dx.doi.org/10.4236/me.2014.513110

Corbeil S., Lynette M. Williams, Jemma Bergfeld, Mark St.J. Crane 2012a. Abalone herpes virus stability in sea water and susceptibility to chemical disinfectants. 326-329: 20-26. 10.1016/j.aquaculture.2011.11.031.

Corbeil S, McColl KA, Williams LM, Mohammad I and others 2012b Abalone viral ganglioneuritis: establishment and use of an experimental immersion challenge system for the study of abalone herpes virus infections in Australian abalone. Virus Res 165: 207-213

Corbeil S., Williams L.M., Kube P., King H., Elliott N and Crane M. St. J. 2013. Fisheries Research and Development Corporation Project - Final Report - 2011/003 - Investigation into the genetic basis of resistance to infection by abalone herpes-like-virus. http://www.frdc.com.au/documentlibrary/finalreports/2011-003-DLD.pdf

Corbeil, S., Faury, N., Segarra, A., Renault, T. 2014. Development of an in situ hybridization assay for the detection of ostreid herpesvirus type 1 mRNAs in the Pacific oyster, Crassostrea gigas. Journal of Virological Methods. 211:43-50

Corbeil, S., Williams, L. M., McColl, K. A., Crane, M. S. J. 2016. Australian abalone (Haliotis laevigata, H. rubra and H. conicopora) are susceptible to infection by multiple abalone herpesvirus genotypes. Dis.Aquat. Org. 119:101-106. doi: 10.3354/dao02989

Cowley, J.A., Corbeil, S., Chen, H., Wong, F., Moody, N.J., Ellard, K., et al.(2011. Sequence variations amongst abalone herpes-like virus (AbHV) strains provide insights into its origins in Victoria and Tasmania. In: Proceedings of the First FRDC Australasian Scientific Conference on Aquatic Animal Health, Cairns, July 5-8, 2011. 
Crane M.ST.J., Corbeil S., Fegan M. \& Warner S. 2009. Aquatic Animal Health Subprogram: Development of molecular diagnostic procedures for the detection and identification of herpes-like virus of abalone (Haliotis spp.). ISBN 978064309835 0., 79 pp

Dang V.T., Benkendorff K., Speck P. 2011. In vitro antiviral activity against herpes simplex virus in the abalone Haliotis laevigata J Gen Virol 92 627-637

Dang V.T., Benkendorff K., Corbeil S., Williams L.M., Hoad J., Crane M.S.J., Speck P. 2013. Immunological changes in response to herpesvirus infection in abalone Haliotis laevigata Haliotis rubra hybrids Fish Shellfish Immunol 34 688-691

da Silva PM, Renault T, Fuentes J, Villalba A. 2008 Herpesvirus infection in European flat oysters Ostrea edulis obtained from brood stocks of various geographic origins and grown in Galicia (NW Spain). Dis Aquat Org 78:181-188

Davison, A. J., Trus, B. L. Cheng, N., Steven, A. C., Watson, M. S., Cunningham, C., Le Deuff, R. M., Renault T. 2005. A novel class of herpesvirus with bivalve hosts. J. Gen. Virol. $86: 41-53$.

Davison, A. J., Eberle, R., Ehlers, B., Hayard, G. S., McGeoch, D. J., Minson, A. M., Pellett P.E., Roizman B., Studdert M. J., Thiry E. 2009. The order Herpesvirales. Arch. Virol. 154:171-177.

Degremont L. 2011. Evidence of herpesvirus (OsHV-1) resistance in juvenile Crassostrea gigas selected for high resistance to the summer mortality phenomenon. Aquaculture, 317 (14), 94-98

Dégremont L. 2013. Size and genotype affect resistance to mortality caused by OsHV-1 in Crassostrea gigas. Aquaculture 416: 129-134.

Dégremont L., Guyader T., Tourbiez D., Pépin J.-F. 2013. Is horizontal transmission of the Ostreid herpesvirus OsHV-1 in Crassostrea gigas affected by unselected or selected survival status in adults to juveniles? Aquaculture 408-409: 51-57.

Dégremont L., Lamy J-B., Pépin J.-F., Travers M.-A., Renault T. 2015a. New insight for the genetic evaluation of resistance to ostreid herpesvirus infection, a worldwide disease, in Crassostrea gigas. PlosOne DOI: 10.1371/journal.pone.0127917.

Dégremont L., Nourry M., Maurouard E. 2015b. Mass selection for survival and resistance to OsHV-1 infection in Crassostrea gigas spat in field conditions: response to selection after four generations. Aquaculture 446: 111-121. 
Dégremont L., Garcia C., Standish K.A.Jr. 2015c. Genetic improvement for disease resistance in oysters: A review. J Inv Pathol 131: 226-241.

Dobos P, Hill BJ, Hallett R, Kells DTC, Bescht H, Teninges D. 1979. Biophysical and biochemical characterization of five animal viruses with bisegmented double-stranded RNA genomes. J. Virol. 32:593-605.

Domeneghetti S, Varotto L, Civettini M, Rosani U, Stauder M, Pretto T, et al. 2014. Mortality occurrence and pathogen detection in Crassostrea gigas and Mytilus galloprovincialis closegrowing in shallow waters (Goro lagoon, Italy). Fish \& Shellfish Immunology 41: 37-44. doi: 10.1016/j.fsi.2014.05.023

Du Y., Zhang L., Huang B., Guan X., Li L., Zhang G. 2013. Molecular cloning, characterization, and expression of two myeloid differentiation factor 88 (MyD88) in Pacific oyster, Crassostrea gigas J World Aquacult Soc 44 759-774

Dundon, W.G., Arzul, I., Omnes, E., Robert, M., Magnabosco, C., Zambon, M., Gennari, L., Toffan, A., Terregino, C., Capua, I., Arcangeli, G. 2011. Detection of Type 1 Ostreid Herpes variant (OsHV-1 $\mu$ var) with no associated mortality in French-origin Pacific cupped oyster Crassostrea gigas farmed in Italy. Aquaculture 314:49-52. doi:10.1016/j.aquaculture.2011.02.005

EFSA. 2010. Scientific Opinion of the Panel on Animal Health and Welfare on a request from the European Commission on the increased mortality events in Pacific oysters Crassostrea gigas. EFSA J. 18(11):1894-1853.

EFSA. 2015. Scientific Opinion of the Panel on Animal Health and Welfare on a request from the European Commission on oyster mortality. EFSA Journal 2015;13(6):4122 [59 pp.].

Elston R.A., 1979, Virus-like particles associated with lesions in larval Pacific oysters (C. gigas). J. Invertebr. Pathol. 33, 71-74.

Elston R., Wilkinson M.T., 1985, Pathology, management and diagnosis of oyster velar virus disease (OVVD). Aquaculture 48, 189-210.

Evans O, Paul-Pont I, Hick P, Whittington R. 2014. A simplecentrifugation method for improving the detection of Ostreid herpesvirus-1 (OsHV-1) in natural seawater samples with an assessment of the potential for particulate attachment. J Virol Methods 210: 59-66 
FAO. 2015. Fisheries and aquaculture software. FishStatJ-software for fishery statistical time series. FAO Fisheries and Aquaculture Department Rome http://www.fao.org/fishery/statistics/software/fishstatj/en.

Fleury E., Huvet A. 2012. Microarray analysis highlights immune response of pacific oysters as a determinant of resistance to summer mortality Mar Biotechnol (NY) 14 203-217

Friedman, C. S., Estes, R. M., Stokes, N. A., Burge, C. A., Hargove, J. S., Barber, B. J., Elston, R. A., Burreson, E.M., Reece, K. S. (2005). Herpes virus in juvenile Pacific oysters Crassostrea gigas from Tomales Bay, California, coincides with summer mortality episodes. Dis. Aquat. Org 63(1):33-41.

Fuhrmann M, Petton B, Quillien V, Faury N, Morga B, Pernet F (2016) Salinity influences disease-induced mortality of the oyster Crassostrea gigas and infectivity of the ostreid herpesvirus 1 (OsHV-1). Aquacult Environ Interact 8:543-552. https://doi.org/10.3354/aei00197

Ellard K., Pyecroft S., Handlinger J. \& Andrewartha R. (2009). Findings of disease investigations following the recent detection of AVG in Tasmania. Proceedings of the Fourth National FRDC Aquatic Animal Health Scientific Conference, Cairns, Australia, 22 -24 July 2009

Everett, R. D., Boutell C., McNair C., Grant L., Orr A. (2010). Comparison of the biological activities of several members of the alphaherpesvirus ICP0 family proteins. J. Virol. 84(7):3476-3487.

Ferenczy, M. W., Ranayhossaini, D. J., Deluca, N. A. (2011). Activities of ICP0 involved in the reversal of silencing of quiescent herpes simplex vius 1. J. Virol. 85(10):4993-5002.

Friedman C.S., Estes R.M., Stokes N.A. et al. 2005. Herpes virus in juvenile Pacific oysters Crassostrea gigas from Tomales Bay, California, coincides with summer mortality episodes. Diseases of Aquatic Organisms 63(1):33-41.

Gagnaire B., Soletchnik P., Madec P., Geairon P., Le Moine O., T. Renault 2006 Diploid and triploid Pacific oysters, Crassostrea gigas (Thunberg), reared at two heights above sediment in Marennes-Oleron Basin, France: difference in mortality, sexual maturation and hemocyte parameters.Aquaculture, 254 : 606-616 
Garcia C, Robert M, Arzul I, Chollet B and others (2006) Viral gametocytic hypertrophy of Crassostrea gigas in France: from occasional records to disease emergence? Dis Aquat Org 70:193-199

Garcia C., Thébault A., Dégremont L., Arzul I., Miossec L., Robert M., Chollet B., Francois C., Joly J.-P., Ferrand S., Kerdudou N., Renault T. 2011. Ostreid herpesvirus 1 detection and relationship with Crassostrea gigas spat mortality in France between 1998 and 2006. Veterinary Research 42: 73. http://www.veterinaryresearch.org/content/42/1/73

Green T.J., Montagnani C. 2013. Poly I:C includes a protective antiviral immune response in the Pacific oyster (Crassostrea gigas) against subsequent challenge with Ostreid herpesvirus (OsHV-1 ųvar). Fish \& Shellfish Immunol 35: 382-388.

Green T.J., Benkendorff K., Robinson N., Raftos D., Speck P. 2014a. Anti-viral gene induction is absent upon secondary challenge with double-stranded RNA in the Pacific oyster, Crassostrea gigas. Fish \& Shellfish Immunol 39: 492-497.

Green T.J., Montagnani C., Benkendorff K., Robinson N., Speck P. 2014b. Ontogeny and water temperature influences the antiviral response of the Pacific oyster, Crassostrea gigas. Fish \& Shellfish Immunol 36: 151-157.

Green T.J., Raftos D., Speck P., Montagnani C. 2015a. Antiviral immunity in marine molluscs. J Gen Virol 96: 2471-2482.

Green T.J., Speck P., Geng L., Raftos D., Beard M.R., Helbig K.J. 2015b Oyster viperin retains direct antiviral activity and its transcription occurs via a signalling pathway involving a heat-stable hemolymph protein.J Gen Virol. 2015 Sep 25. doi: 10.1099/jgv.0.000300.

Gu, H., Roizman, B. (2009). The two functions of herpes simplex virus 1 ICP0, inhibition of silencing by the CoREST/REST/HDAC complex and degradation of PML, are executed in tandem. J. Virol. 83(1):181-187.

Hauton C, Hawkins LE, Hutchinson S. The effects of salinity on the interaction between a pathogen (Listonella anguillarum) and components of a host (Ostrea edulis) immune system. Comp Biochem Physiol B Biochem Mol Biol. 2000. 127(2):203-12

He Y., Jouaux A., Ford S.E., Lelong C., Sourdaine P., Mathieu M., Guo X. 2015. Transcriptome analysis reveals strong and complex antiviral response in a mollusc Fish Shellfish Immunol 46 131-144 
Hick P., Evans O., Looi R., English C., Whittington R.J. 2016. Stability of Ostreid herpesvirus-1 (OsHV-1) and assessment of disinfection of sea water and oyster tissues using a bioassay. Aquaculture 450: 412-421.

Hill, B. J. 1976. Mollusc viruses: their occurrence, culture and relationships. In Proceedings of the first international colloquium on invertebrate pathology. p 25-29.

Hine, P.M., Wesney, B., Hay, B. 1992. Herpesvirus associated with mortalities among hatchery-reared larval Pacific oysters Crassostrea gigas, Dis. Aquat. Org. 12:135-142.

Hine PM, Thorne T 1997 Replication of herpes-like viruses in haemocytes of adult flat oysters Ostrea angasi: an ultra-structural study. Dis Aquat Org 29:189-196

Hooper, C., Hardy-Smith, P., Handlinger, J. 2007 Ganglioneuritis causing high mortalities in farmed Australian abalone (Haliotis laevigata and Haliotis rubra). Aus. Vet. J. 85(5):188-193.

Hosono, N., Suzuki, S., Kusuda, R. (1996). Genogrouping of birnaviruses isolated from marine fish: a comparison of VP2/NS junction regions on genome segment A. J. Fish Dis. 19:295-302.

Inaba, M., Suzuki, S., Kitamura, S.I., Kumazawa, N., Kodama, H. 2009. Distribution of Marine Birnavirus (MABV) in marine organims from Okinawa, Japan, and a unique sequence variation of the VP2/NS region. J. Microbiol. 47:76-84.

Jemaà M., Morin N., Cavelier P., Cau J., Strub J.M., Delsert C. 2014 Adult somatic progenitor cells and hematopoiesis in oyster Journal of Experimental Biology. 10.1242

Jenkins C., Hick P., Gabor M., Spiers Z., Fell S.A., Gu X.N., Read A., Go J., Dove M., O'Connor W., Kirkland P. D. \& Frances J. 2013. Identification and characterisation of an ostreid herpesvirus-1 microvariant (OsHV-1 mu-var) in Crassostrea gigas (Pacific oysters) in Australia. Dis. Aquat. Org., 105, 109-126

Jouaux A., Lafont M., Blin J.-L., Houssin M., Mathieu M., Lelong C. 2013. Physiological change under OsHV-1 contamination in Pacific oyster Crassostrea gigas through massive mortality events on fields BMC Genomics 14590

Kazama F and Schornstein K.L. 1972 Herpes-type virus particles associated with a fungus. Science $177,686-697$

Keeling, S.E., Brosnahan, C.L., Williams, R., Gias, E., Hannah, M., Bueno, R., McDonald, W.L., Johnston, C. 2014. New Zealand juvenile oyster mortality associated with ostreid 
herpesvirus 1-an opportunistic longitudinal study. Dis. Aquat. Organ. 109:231-239. doi:10.3354/dao02735

Labanov, V. A., Maher-Sturgess, S. L., Snider, M. G., Lawman, Z., Babiuk, L. A., van Drunen Littel-van den Hurk S. 2010. A UL47 gene deletion mutant of Bovine Herpesvirus type 1 exhibits impaired growth in cell culture and lack of virulence in cattle. J. Virol. 84(1):445458.

Le Deuff R.M., Nicolas J.L., Renault T. \& Cochennec N. 1994. Experimental transmission of a herpes-like virus to axenic larvae of Pacific oyster, Crassostrea gigas. Bull. Eur. Assoc. Fish Pathol., 14, 69-72

Le Deuff R.M., Renault T. \& Gerard A. 1996. Effects of temperature on herpes-like virus detection among hatchery-reared larval Pacific oyster Crassostrea gigas. Dis. Aquat. Org., 24, $149-157$

Le Deuff, R. M., Renault, T. 1999. Purification and partial genome characterization of a herpes-like virus infecting the Japanese oyster, Crassostrea gigas. Journal of General Virology 80:1317-22.

Li Y., Zhang L., Qu T., Li L., Zhang G. 2016 Characterization of Oyster Voltage-Dependent Anion Channel 2 (VDAC2) Suggests Its Involvement in Apoptosis and Host Defense. PLoS One. Jan 4;11(1):e0146049. doi: 10.1371/journal.pone.0146049.

Lipart, C., Renault, T. 2002. Herpes-like virus detection in Crassostrea gigas spat using DIGlabelled probes. Journal of Virological Methods 101:1-10.

Lo, C -F., Hong, Y.-W., Huang, S.-Y., Wang, C.-H. 1988. The characteristics of the virus isolated from the gill of clam, Meterix lusoria. Fish Pathol. 23 (3): 147-154

Lomniczi, B., Watanabe, S., Ben-Porat, T., Kaplan, A. S. 1987. Genome location and identification of functions defective in the Bartha vaccine strain of pseudorabies virus. J. Gen. Virol. 61(3):796-801.

López Sanmartín M., Power D.M., de la Herrán R., Navas J.I, F. Batista. 2016. Experimental infection of European flat oyster Ostrea edulis with ostreid herpesvirus 1 microvar (OsHV-1 $\mu$ var): Mortality, viral load and detection of viral transcripts by in situ hybridization, Virus Research 217: 55-62 
Lynch, S.A., Carlson, J., Reilly, A.O., Cotter, E., Culloty, S.C. 2012. A previously undescribed ostreid herpesvirus 1 (OsHV-1) genotype detected in the Pacific oyster, Crassostrea gigas, in Ireland. Parasitology 139:1526-32.

Martenot, C., Oden, E., Travaillé, E., Malas, J. P., Houssin, M. 2010. Comparison of two realtime PCR methods for detection of ostreid herpesvirus 1 in the Pacific oyster Crassostrea gigas. Journal of Virological Methods 170:87-90.

Martenot, C., Oden, E., Travaillé, E., Malas, J.-P., Houssin, M. 2011. Detection of different variants of Ostreid Herpesvirus 1 in the Pacific oyster, Crassostrea gigas between 2008 and 2010. Virus Res. 160 :25-31. doi:10.1016/j.virusres.2011.04.012

Martenot, C., Travaillé, E., Lethuillier, O., Lelong, C., Houssin, M. 2013. Genome exploration of six variants of the Ostreid Herpesvirus 1 and characterization of large deletion in OsHV$1 \mu$ Var specimens. Virus Res. 178:462-470. doi:10.1016/j.virusres.2013.08.006

Martenot C., Denechère L., Hubert P., Metayer L., Oden E., Trancart S., Travaillé E., Houssin M. 2015. Detection of undescribed ostreid herpesvirus 1 (OsHV-1) specimens from Pacific oyster, Crassostrea gigas. J Invertebr Pathol. ;132:182-9. doi: 10.1016/j.jip.2015.10.005.

Martenot C, Segarra A, Baillon L, Faury N, Houssin M, Renault T. 2016 In situ localization and tissue distribution of ostreid herpesvirus 1 proteins in infected Pacific oyster, Crassostrea gigas. J Invertebr Pathol. 136:124-35. doi: 10.1016/j.jip.2016.04.002. Epub 2016 Apr 8.

Martínez Martínez J, Swan BK, Wilson WH. 2014. Marine viruses, a genetic reservoir revealed by targeted viromics. ISME J. 8(5):1079-88. doi: 10.1038/ismej.2013.214.

Meyers T.R. 1984. Marine molluscs as reservoirs of viral finfish pathogens: significance to marine and anadromous finfish aquaculture. Mar. Fish. Rev. 46, 14-17

Meyers, T. R., Burton, T., Evans, W., Starkey, N. 2009. Detection of viruses and virus-like particles in four species of wild and farmed bivalve molluscs in Alaska, USA, from 1987 to 2009. Dis. Aquat. Org. 88:1-12.

Miossec L., Allain G., Arzul I., Francois C., Garcia C., Cameron A. 2009. First results of an epidemiological study on oyster (Crassostrea gigas) mortality events in France during summer 2008. ISVEE XII - International Symposium on Veterinary Epidemiology and Economics. http://archimer.ifremer.fr/doc/00000/6772/ 
Moreau P., Moreau K., Segarra A., Tourbiez D., Travers M.-A., Rubinsztein D.C., Renault T. 2015. Autophagy plays an important role in protecting Pacific oysters from OsHV-1 and Vibrio aestuarianus infections Autophagy 11 516-526)

Moss, J.A., Burreson, E.M., Cordes, J.F., Cungan, C.F., Brown, G.D., Wang, A., Wu, X., Reece, K.S. 2007. Pathogens in Crassostrea ariakensis and other Asian oyster species: implications for non-native oyster introduction in Chesapeake Bay. Dis. Aquat. Org. 77:207233.

Moriuchi, H., Moriuchi, M., Cohen, J. I. 1994. the RING finger domain of the VaricellaZoster virus open reading frame 61 protein is required for its transregulatory functions. Virology 205:238-246.

Nicolas, J.L., Comps, M., Cochennec, N., 1992. Herpes-like virus infecting Pacific oyster larvae, Crassostrea gigas. Bull. Eur. Assoc. Fish Pathol. 12, 11-13.

Nobiron, I., Galloux, M., Henry, C., Torhy, C., Boudinot, P., Lejal, N., Da Costa, B., Delmas, B. 2008. Genome and polypetides characterization of Tellina virus 1 reveals a fifth genetic cluster in the Birnaviridae family. Virology 371:350-361.

Normand J., Blin J-L., Jouaux A. 2014a. Rearing practices identified as risk factors for ostreid herpesvirus 1 (OsHV-1) infection in Pacific oyster Crassostrea gigas spat. Dis Aquat Org 110: 201-211.

Normand J., Li R., Quillien V., Nicolas J.-L., Boudry P., Pernet F., Huvet A. 2014b. Contrasted survival under field or controlled conditions displays associations between mRNA levels of candidate genes and response to OsHV-1 infection in the Pacific oyster Crassostrea gigas Mar Genomics 15 95-102

Oden, E., Martenot, C., Travaillé, E., Malas, J.P., Houssin, M. 2011.Quantification of ostreid herpesvirus1(OsHV-1)in Crassostrea gigas by real-time PCR: Determination of a viral load threshold to prevent summer mortalities. Aquaculture 317:27-31.

Olicard C., Didier Y., Marty C., Bourgougnon N., Renault T. 2005a. In vitro research of antiHSV-1 activity in different extracts from Pacific oysters Crassostrea gigas Dis Aquat Organ $67141-147$

Olicard C., Renault T., Torhy C., Benmansour A., Bourgougnon N. 2005b. Putative antiviral activity in hemolymph from adult Pacific oysters, Crassostrea gigas Antiviral Res 66 147152 
Paul-Pont I, Dhand NK, Whittington RJ 2013a Spatial distribution of mortality in Pacific oysters Crassostrea gigas: reflection on mechanisms of OsHV-1 transmission. Dis Aquat Org 105: $127-138$

Paul-Pont I, Dhand NK, Whittington RJ 2013b Influence of husbandry practices on OsHV-1 associated mortality of Pacific oysters Crassostrea gigas. Aquaculture 412-413: 202-214

Paul-Pont, I., Evans, O., Dhand, N.K., Rubio, A., Coad, P., Whittington, R.J. 2014. Descriptive epidemiology of mass mortality due to Ostreid herpesvirus-1 (OsHV-1) in commercially farmed Pacific oysters (Crassostrea gigas) in the Hawkesbury River estuary, Australia. Aquaculture 422-423:146-159. doi:10.1016/j.aquaculture.2013.12.009

Paul-Pont I, Evans O, Dhand NK, Rubio A, Coad P, Whittington RJ 2014 Descriptive epidemiology of mass mortality due to Ostreid herpesvirus-1 (OsHV-1) in com mercially farmed Pacific oysters (Crassostrea gigas) in the Hawkes bury River estuary, Australia. Aquaculture 422-423: 146-159

Paul-Pont I, Evans O, Dhand NK, Whittington RJ 2015 Experimental infections of Pacific oyster Crassostrea gigas using the Australian ostreid herpesvirus-1 (OsHV-1) $\mu$ Var strain. Dis Aquat Org 113:137-147

Peeler, E.J., Reese, R.A., Cheslett, D.L., Geoghegan, F., Power, A., Thrush, M.A. 2012. Investigation of mortality in Pacific oysters associated with Ostreid herpesvirus-1 $\mu$ Var in the Republic of Ireland in 2009. Prev. Vet. Med. 105:136-143. doi:10.1016/j.prevetmed.2012.02.001

Pepin, J. F., Riou, A., Renault, T. 2008. Rapid and sensitive detection of ostreid herpesvirus A in oysters samples by real-time PCR. Journal of Virological Methods 149(2):269-76.

Pernet, F., Barret, J., Le Gall, P., Corporeau, C., Dégremont, L., Lagarde,F., Pepin, J.F., Keck, N., 2012. Mass mortalities of Pacific oysters Crassostrea gigas reflect infectious diseases and vary with farming practices in the Mediterranean Thau lagoon, France. Aquacult. Envi-ron. Interact. 2, 215-237.

Pernet F, Lagarde F, Jeanne'e N, Daigle G, Barret J, et al. 2014 Spatial and Temporal Dynamics of Mass Mortalities in Oysters Is Influenced by Energetic Reserves and Food Quality. PLoS ONE 9(2): e88469. doi:10.1371/journal.pone.0088469 
Petton, B., Pernet, F., Robert, R., Boudry, P., 2013. Temperature influence on pathogen transmission and subsequent mortalities in juvenile Pacific oysters Crassostrea gigas. Aquac. Environ. Interact. 3, 257-273

Ren, W., Chen, H. X., Renault, T., Cai, Y. Y., Bai, C. M., Wang, C. M., Huang, J. 2013 Complete genome sequence of acute viral necrosis virus associated with massive mortality outbreaks in the Chinese scallop, Chlamys farreri. Virol. J. 10:110

Renault, T. and B. Novoa. 2004. Viruses infecting bivalve molluscs. Aquatic Living Resources 17: 397-409.

Renault, T. 2009. Controlling viral diseases in aquaculture: new insights. In New Technologies in Aquaculture: Improving Production Efficiency, Quality and Environmental management. Eds G. Burnell and G. Allan. CRC Press, Woodstock Publishing Limited, Cambridge, pp 244-259

Renault, T. 2012. Pacific cupped oyster, Crassostrea gigas, mortality outbreaks and infectious diseases. In Oysters: Physiology, Ecological Distribution and Mortality. Ed Jian G. Qin. Nova Sciences Publishers, ISBN: 978-1-62100-557-5

Renault, T., Cochennec, N., Le Deuff, R.M., Chollet B. 1994a Herpes-like virus infecting Japanese oyster (Crassostrea gigas) spat. Bulletin of European Association of Fish Pathologists 14:64-6.

Renault, T., Le Deuff, R.-M., Cochennec, N., Maffart P. 1994b. Herpesviruses associated with mortalities among Pacific oyster, Crassostrea gigas, in France - comparative study. Revue de Médecine Vétérinaire 145:735-42.

Renault, T., Le Deuff, R.M., Cochennec, N., Chollet, B., Maffart, P. 1995. Herpes-like viruses associated with high mortality levels in larvae and spat of Pacific oysters, Crassostrea gigas: A comparative study, the thermal effects on virus detection in hatchery-reared larvae, reproduction of the disease in axenic larvae. Veterinary Research 26:539-43.

Renault T., Le Deuff, R.-M., Lipart, C., Delsert C. 2000. Development of a PCR procedure for the detection of a herpes-like virus infecting oysters in France. Journal of Virological Methods 88:41-50.

Renault, T., Arzul, I. 2001. Herpes-like virus infections in hatchery-reared bivalve larvae in Europe: specific viral DNA detection by PCR. Journal of Fish Diseases 24(3):161-67. 
Renault, T., Lipart C., Arzul I. 2001a.A herpes-like virus infecting Crassostrea gigas and Ruditapes philipinarum larvae in France. J. Fish Dis. 24:369-376.

Renault, T., Lipart, C., Arzul, I. 2001b. A herpes-like virus infects a non-ostreid bivalve species: virus replicaton in Ruditapes philippinarum larvae. Dis. Aqua. Org. 45:1-7.

Renault T., Solliec G. and Arzul I. 2003 Détection d'un virus de type herpes chez un champignon present dans les élevages larvaires d'huître creuse, Crassostrea gigas. Virologie 7, (numéro spécial) S37.

Renault T., Faury N., Barbosa-Solomieu V., Moreau K. 2011. Suppression substractive hybridisation $(\mathrm{SSH})$ and real time PCR reveal differential gene expression in the Pacific cupped oyster, Crassostrea gigas, challenged with Ostreid herpesvirus 1 Dev Comp Immunol $35725-735$

Renault, T., Moreau, P., Faury, N., Pepin, J.F., Segarra, A., Webb, S. 2012. Analysis of Clinical Ostreid Herpesvirus 1 (Malacoherpesviridae) Specimens by Sequencing Amplified Fragments from Three Virus Genome Areas. Journal of Virology 86(10):5942-47. doi:10.1128/JVI.06534-11

Renault, T., Tchaleu, G., Faury, N. et al. 2014. Genotyping of a microsatellite locus to differentiate clinical Ostreid herpesvirus 1 specimens. Veterinary Research 45:3-11.

Renault, T., Bouquet, A.L., Maurice, J.-T., Lupo, C., Blachier, P., 2014. Ostreid, herpesvirus 1 infection among Pacific oysters, Crassostrea gigas, spat: virus replication and circulation related to water temperature prior the onset of mortality, Appl. Environ. Microbiol 80 (17), $5419-5426$.

Roque, A., Carrasco, N., Andree, K. B., Lacuesta, B., Elandaloussi, L., Gairin, I., Rodgers, C. J., Furones, M. D. 2012. First report of OsHV-1 microvar in Pacific oyster (Crassostrea gigas) cultured in Spain. Aquaculture 324-325:303-306. doi:10.1016/j.aquaculture.2011.10.018

Rosani U., Varotto L., Domeneghetti S., Arcangeli G., Pallavicini A., Venier P. 2015. Dual analysis of host and pathogen transcriptomes in ostreid herpesvirus 1-positive Crassostrea gigas Environ Microbiol.

Savin, K. W., Cocks, B. G., Wong, F., Sawbridge, T., Cogan, N., Savage, D., Warner, S. 2010. A neurotropic herpesvirus infecting the gastropod, abalone, shares ancestry with oyster herpesvirus and a herpesvirus associated with the amphioxus genome. Virol. J. 17:308-317. 
Sauvage C., Pepin J.F., Lapegue S., Boudry P. \& Renault T. (2009). Ostreid herpes virus 1 infection in families of the Pacific oyster, Crassostrea gigas, during a summer mortality outbreak: difference in viral DNA detection and quantification using real-time PCR. Virus Res., 142, 181-187

Schikorski D., Faury N., Pepin J.F., Saulnier D., Tourbiez D. \& Renault T. 2011a. Experimental ostreid herpesvirus 1 infection of the Pacific oyster Crassostrea gigas: kinetics of virus DNA detection by q-PCR in seawater and in oyster samples. Virus Res., 155 (1), 2834

Schikorski D., Renault T., Saulnier D., Faury N., Moreau P. \& Pepin J.F. 2011b. Experimental infection of Pacific oyster Crassostrea gigas spat by ostreid herpesvirus 1: demonstration of oyster spat susceptibility. Vet. Res., 42, 1-13

Segarra, A., Pépin, J.F., Arzul, I., Morga, B., Faury, N., Renault, T. 2010. Detection and description of a particular Ostreid herpesvirus 1 genotype associated with massive mortality outbreaks of Pacific oysters, Crassostrea gigas, in France in 2008. Virus Research. 153:92-99. doi:10.1016/j.virusres.2010.07.011

Segarra A., Baillon L., Tourbiez D., Benabdelmouna A., Faury N., Bourgougnon N., Renault T. 2014a. Ostreid herpesvirus type 1 replication and host response in adult Pacific oysters, Crassostrea gigas Vet Res 45103

Segarra, A., Faury, N., Pépin, J.-F., Renault, T. 2014b. Transcriptomic study of 39 ostreid herpesvirus 1 genes during an experimental infection. Journal of Invertebrate Pathology 119:5-11.

Segarra, A., Mauduit, F., Faury, N. et al. 2014c. Dual transcriptomics of virus-host interactions: comparing two Pacific oyster families presenting contrasted susceptibility to ostreid herpesvirus 1. BMC Genomics 15:580-91.http://www.biomedcentral.com/1471$2164 / 15 / 580$

Shimahara, Y., Kurita, J., Kiryu, I., Nishioka, T., Yuasa, J., Kawana, M., Kamaishi, T., Oseko, N. 2012. Surveillance of Type 1 Ostreid Herpesvirus (OsHV-1) Variants in Japan. Fish Pathol. 47(4):129-136.

Spatz, S. J., Rue, C. A. 2008. Sequence determination of a mildy virulent strain (CU-2) of Gallid herpesvirus type 2 using 454 pyrosequencing. Virus Genes 36(3):479-489. 
Spatz, S. J., Silva, R. F. 2007. Polymorphisms in the repeat long regions of oncogenic and attenuated pathotypes of Marek's diseases virus 1.Virus Genes 35(1):41-53.

Suzuki, S., Hosono, N., Kusuda, R. 1997. Detection of aquatic birnavirus gene from marine fish using a combination of reverse transcription and nested PCR. J. Mar. Biotech. 5:205-209. Suzuki, S., Kamakura, M., Kusuda, R. 1998a. Isolation of birnavirus from Japanese Pearl oyster Pinctada fucata. Fish Sci. 64:342-343.

Suzuki, S., Utsunomiy, I., Kusuda, R. 1998b. Experimental infection of marine birnavirus strain JPO-96 to Japanese pearl oyster Pinctada fucata. Bull. Mar. Sci. Fish Kochi Univ 18:39-41.

Suzuki, S., Nakata, T., Kamakura, M., Yoshimoto, M., Furakawa, Y., Yamashita, Y., Kusuda, R. (1998c). Isolation of birnavirus from Agemaki (Jack Knife Clam) Sinovacura consticta and survey of the virus using PCR technique. Fish Sci. 63:563-566.

Tamayo D., Corporeau C., Petton B., Quere C., Pernet F. 2014. Physiological changes in Pacific oyster Crassostrea gigas exposed to the herpesvirus OsHV-1 $\mu$ var Aquaculture 432 304-310

Tan, J., Lancaster, M., Hyatt, A., Van Driel, R., Waong, F., Warner, S. 2008. Purification of a herpes-like virus from abalone (Haliotis spp.) with ganglioneuritis and detection by transmission electron microscopy. J. Virol. Methods 149:338-341.

Tang B., Liu B., Wang X., Yue X., Xiang J. 2010. Physiological and immune responses of Zhikong scallop Chlamys farreri to the acute viral necrobiotic virus infection Fish Shellfish Immunol $2942-48$

Van Regenmortal, M. H. V. 2008. Virus species. In:Mahy, B. W. J. and Van Regenmortel, M. (eds.), Encyclopedia of Virology, 3rd edition. Academic Press, pp. 401-406.

Vásquez-Yeomans, R., García-Ortega, M., Cáceres-Martínez, J. 2010. Gill erosion and herpesvirus in Crassostrea gigas cultured in Baja California, Mexico. Dis. Aquat. Organ. 89(2):137-44.

Vigneron V., Solliec G., Montanie H. \& Renault T. 2004. Detection of ostreid herpes virus 1 (OsHV-1) DNA in seawater by PCR: influence of water parameters in bioassays. Dis. Aquat. Org., 62, 35-44 
Wang C, Wang X, Song X, Huang J, SongW. 2002 Purification and ultrastructure of a spherical virus in cultured scallop, Chlamys farreri. J Fish Chin 26: 180-184

Webb, S.C., Fidler, A., Renault, T. 2007. Primers for PCR-based detection of ostreid herpes virus-1 (OsHV-1): Application in a survey of New Zealand molluscs. Aquaculture 272:12639.

Weitz J.S. and S.W. Wilhelm ; 2012. Ocean viruses and their effects on microbial communities and biogeochemical cycle. F1000 Biology Reports 2012, 4:17

Whittington RJ, Dhand NK, Evans O, Paul-Pont I. 2015a Further observations on the influence of husbandry practices on OsHV-1 ìvar mortality in Pacific oysters Crassostrea gigas : age, cultivation structures and grow- ing height. Aquaculture 438: 82-97

Whittington RJ, Hick P, Evans O, Rubio A, Alford B, Dhand N, Paul-Pont I 2015b Protection of Pacific oyster (Crassostrea gigas) spat from mortality due to Ostreid herpesvirus 1 (OsHV1 ìvar) using simple treatments of in coming seawater in land-based upwellers. Aquaculture 437: $10-20$

World Organisation for Animal HealthGeneral (OIE) 2011a. Ostreid herpesvirus- $\mu$ variant, Australia, http://web.oie.int/wahis/public.php?page=single_report\&pop=1\&reportid=10235

World Organisation for Animal HealthGeneral (OIE), 2011b. Ostreid herpesvirus-1, New Zealand, http://web.oie.int/wahis/public.php?page=single_report\&pop=1\&reportid=1023

World Organisation for Animal HealthGeneral (OIE) 2014. Recommendation Disease Prevention and Control. Chapter 4.1. Seventeenth Edition http://www.oie.int/doc/ged/D13873.PDF

World Organisation for Animal Health (OIE) 2015. Chapter 4.1. Zoning and compartmentalisation.http://www.oie.int/fileadmin/Home/eng/Health_standards/aahc/2010/en _chapitre_zon_c

Xia, J., Bai, C., Wang, C., Song, X., Huang, J. 2015. Complete genome sequence of Ostreid herpesvirus-1 associated with mortalities of Scapharca broughtonii broodstocks. Virol. J. 12:110. doi: 10.1186/s12985-015-0334-0.

Xing J., Lin T., Zhan W. 2008. Variations of enzyme activities in the haemocytes of scallop Chlamys farreri after infection with the acute virus necrobiotic virus (AVNV) Fish Shellfish Immunol $25847-852$ 
Zanjani N.T., Sairi F., Marshall G., Saksena M.M., Valtchev P., Gomes V.G., Cunningham A.L., Dehghani F. 2014. Formulation of abalone hemocyanin with high antiviral activity and stability Eur J Pharm Sci 53 77-85

Zeng M., Cui W., Zhao Y., Liu Z., Dong S., Guo Y. 2008. Antiviral active peptide from oyster Chin J Oceanology Limnol 26 307-312

Zhang, C. X., Suzuki, S. 2003. Comparaison the RNA polymerase genes of marine birnavirus strains and other birnaviruses. Arch. Virol. 148:745-758.

Zhang, C. X., Suzuki, S. 2004. Aquabirnaviruses isolated from marine organisms form a distinct genogroup form other aquabirnaviruses. J; Fish Dis. 27:633-643.

Zhang G., Fang X., Guo X., Li L., Luo R., Xu F., et al. 2012 The oyster genome reveals stress adaptation and complexity of shell formation; Nature, 490: 49-54 


\section{Figure captions}

Figure 1. Preliminary approach for selection of virus genes of interest. M: molecular markers (Eurogentec), 1: 1994/006/France, 2: 1995/020/France, 3: 2008/055/France, 4: 2010/012/France and N: negative control. (A) PCR products from 4 virus isolates electrophoresed on $1.5 \%$ agarose using primer pairs targeting ORFs 37

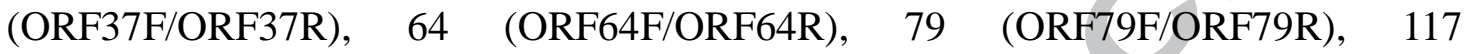
(ORF117F/ORF117R) and 121 (ORF121F/ORF121R). (B) PCR products from 4 virus isolates electrophoresed on $1.5 \%$ agarose using the primer pair targeting the ORFs 35/36/37/38 area (Del 36-37F2/Del 36-37R).

Figure 2. Hematoxylin and eosin stained histological section from Crassostrea gigas infected with OsHV-1. Scale bar $=10 \mu \mathrm{m}$. Condensed hyperbasophilic nuclei (arrows) and nuclei with marginated chromatin (arrow heads) observed in the connective tissue of the mantle (Photograph by Bruno Chollet, LGPMM, Ifremer).

Figure 3. Hematoxylin and eosin stained histological section from Ostrea edulis infected with

OsHV-1. Scale bar $=10 \mu \mathrm{m}$. Large intranuclear acidophilic inclusions similar to Cowdry type A inclusions (arrow heads) observed in the connective tissue of the mantle (Photograph by Bruno Chollet, LGPMM, Ifremer).

Figure 4. Transmission electron micrographs of OsHV-1 infected cells. Enveloped viral particles in Pacific cupped oyster larva. Scale bar $=500 \mathrm{~nm}$.

Figure 5. Transmission electron micrographs of OsHV-1 infected cells. An enveloped viral particle inside the mantle in a Pacific cupped oyster spat (star). Scale bar $=1 \mu \mathrm{m}$ 
Figure 6. The inability of the abalone to fully adhere to the side of the tank (arrow) is usually the first sign of morbidity shown by abalone affected by abalone viral ganglioneuritis. (Photograph by Lynette Williams, CSIRO-AAHL)

Figure 7. Blister on the foot of a hybrid abalone (blacklip $\mathrm{X}$ greenlip). This pathognomonic sign of abalone viral ganglioneuritis appeared 4 days after infection through immersion challenge. (Photograph by Lynette Williams, CSIRO-AAHL)

Figure 8. Hematoxylin and eosin stained histological section from Haliotis diversicolor supertexta infected with AbHV. Scale bar $=100 \mu \mathrm{m}$. Increased hemocytic infiltration and necrosis in a nerve (Photograph by Bruno Chollet, LGPMM, Ifremer).

Figure 9. Transmission electron micrograph of ultrathin section of pleuropedal ganglion from an abalone herpesvirus-infected abalone. $\mathrm{N}$ : nucleus; $\mathrm{C}$ : cytoplasm; black arrows: enveloped viral particles; white arrows: incomplete viral particles (Photograph by Hyatt A., AAHL, CSIRO). 


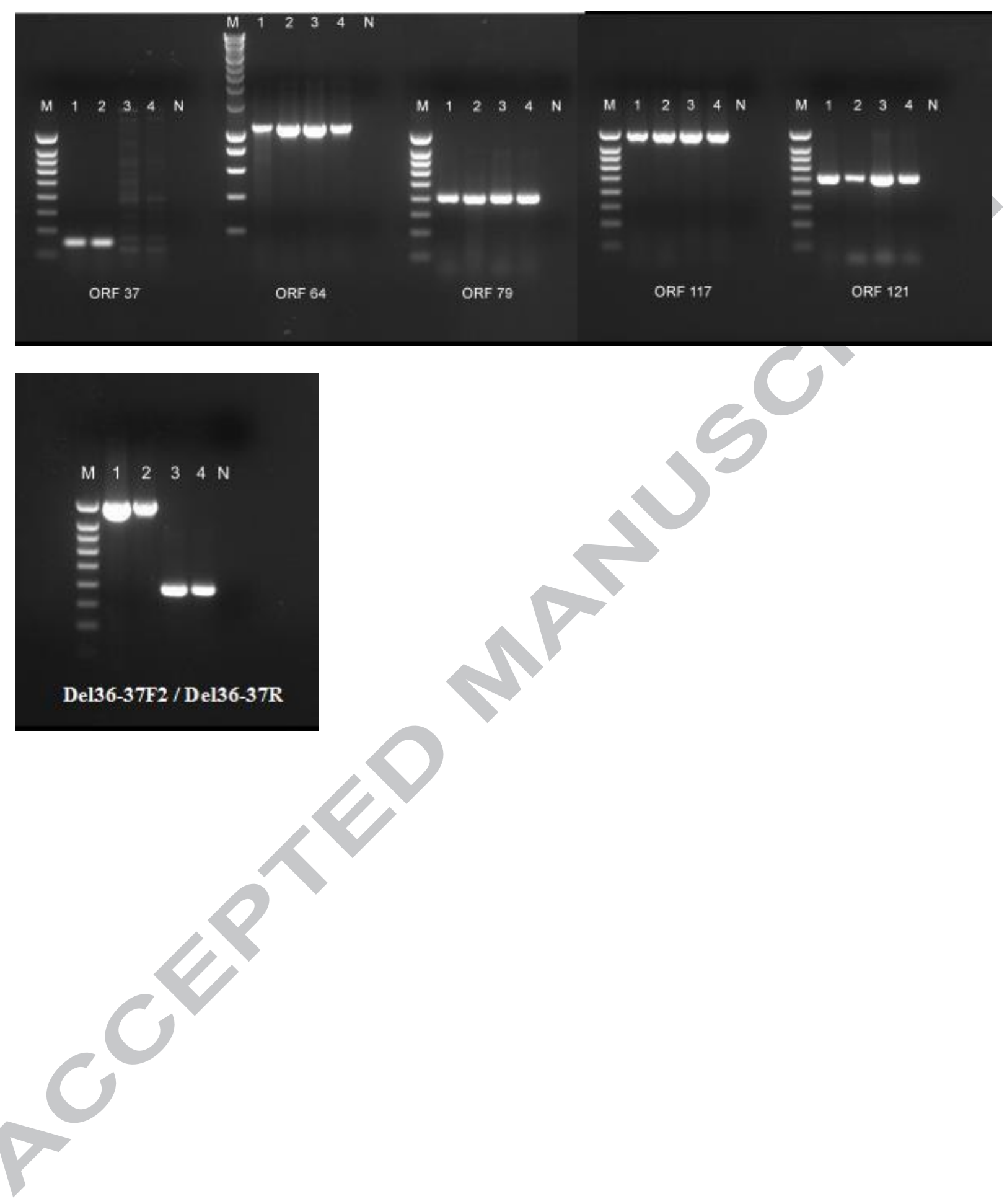



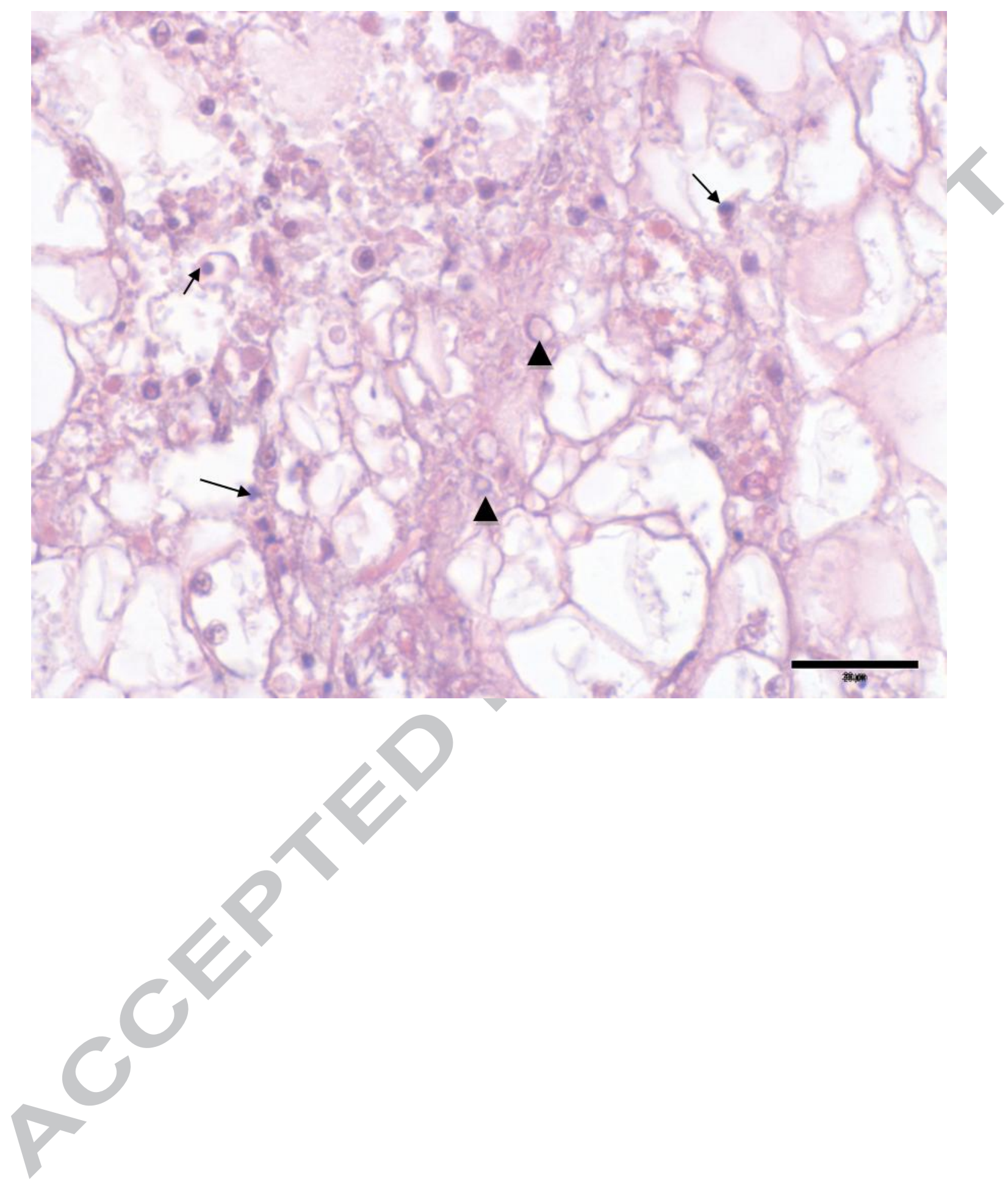


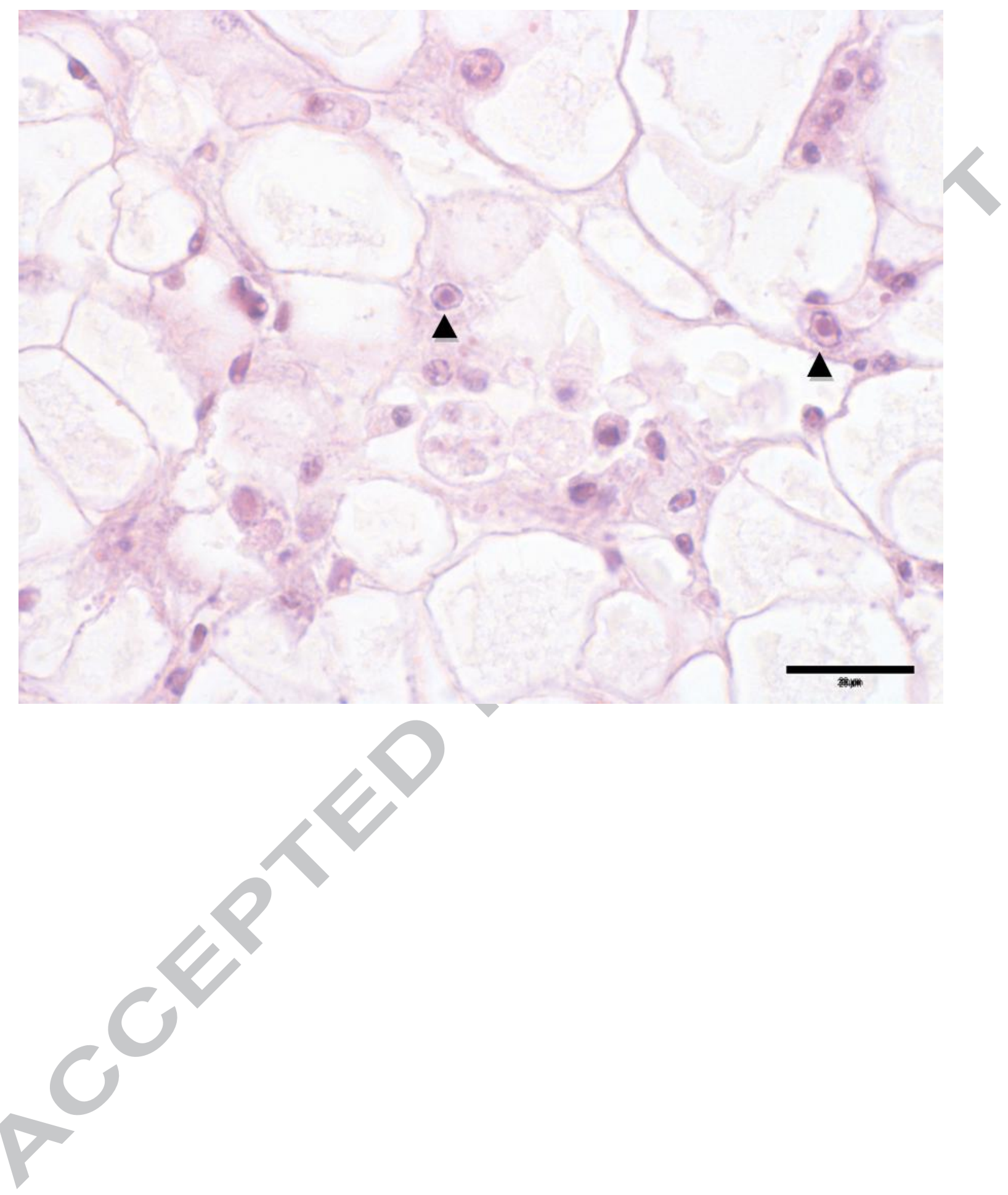




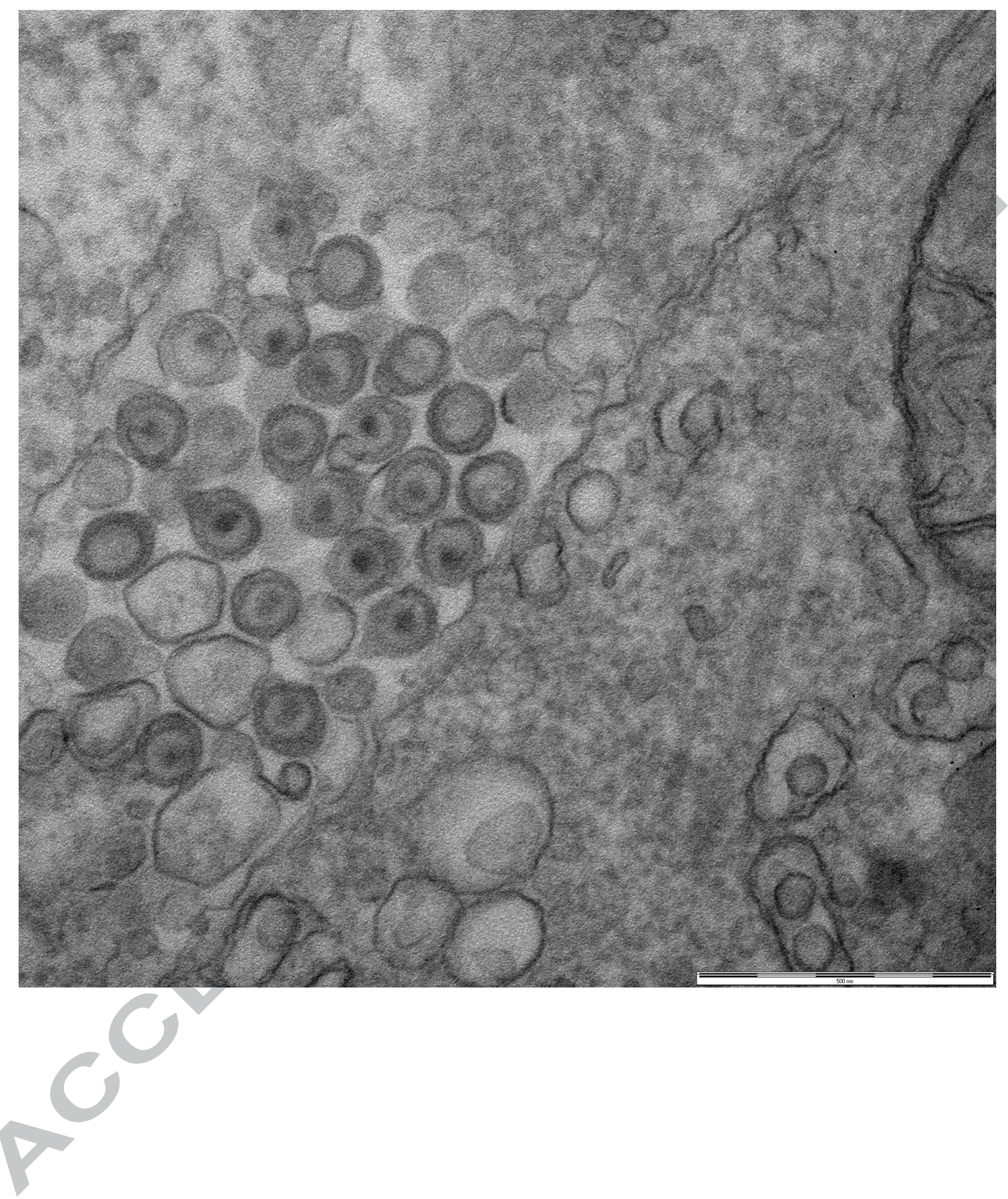




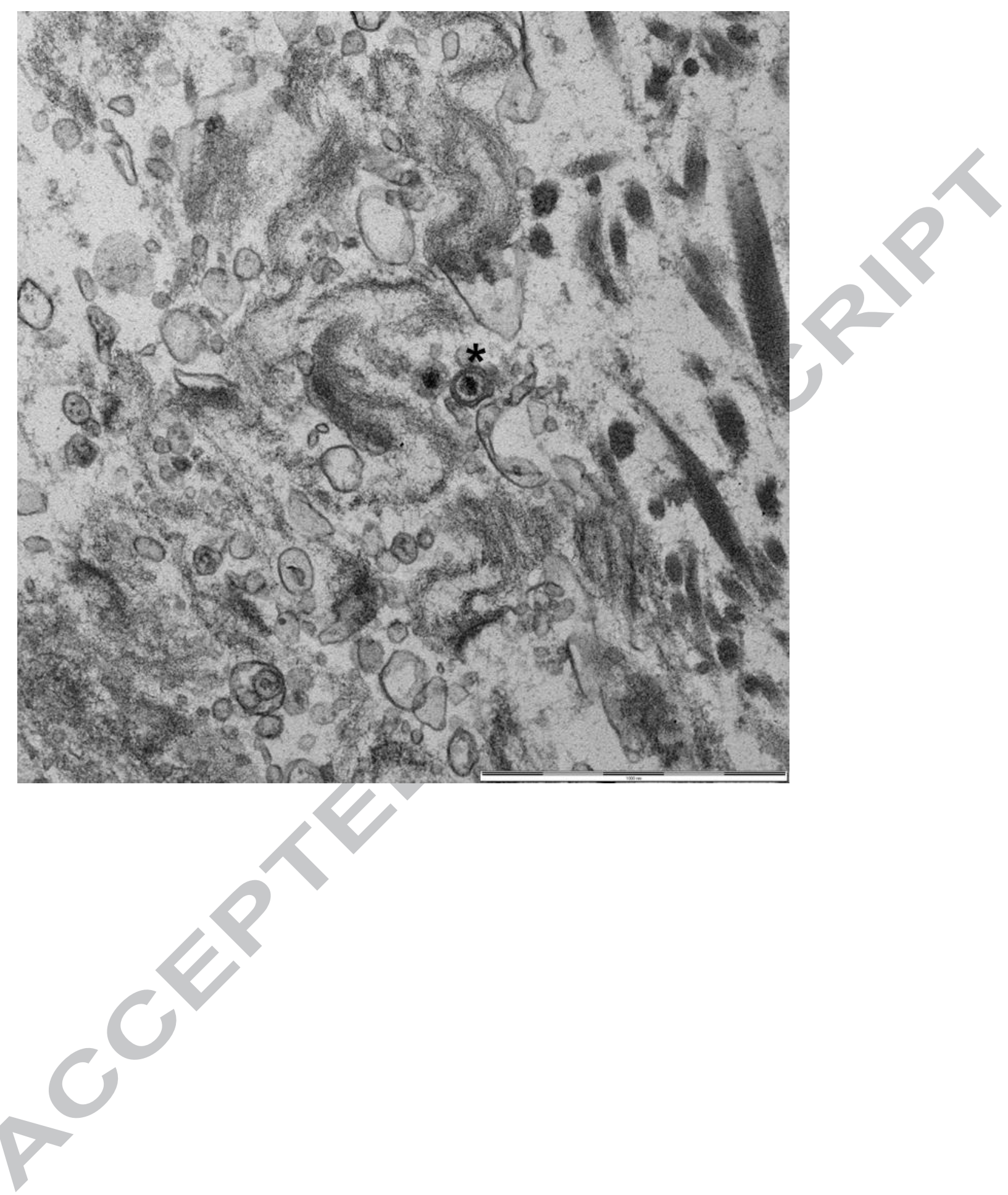




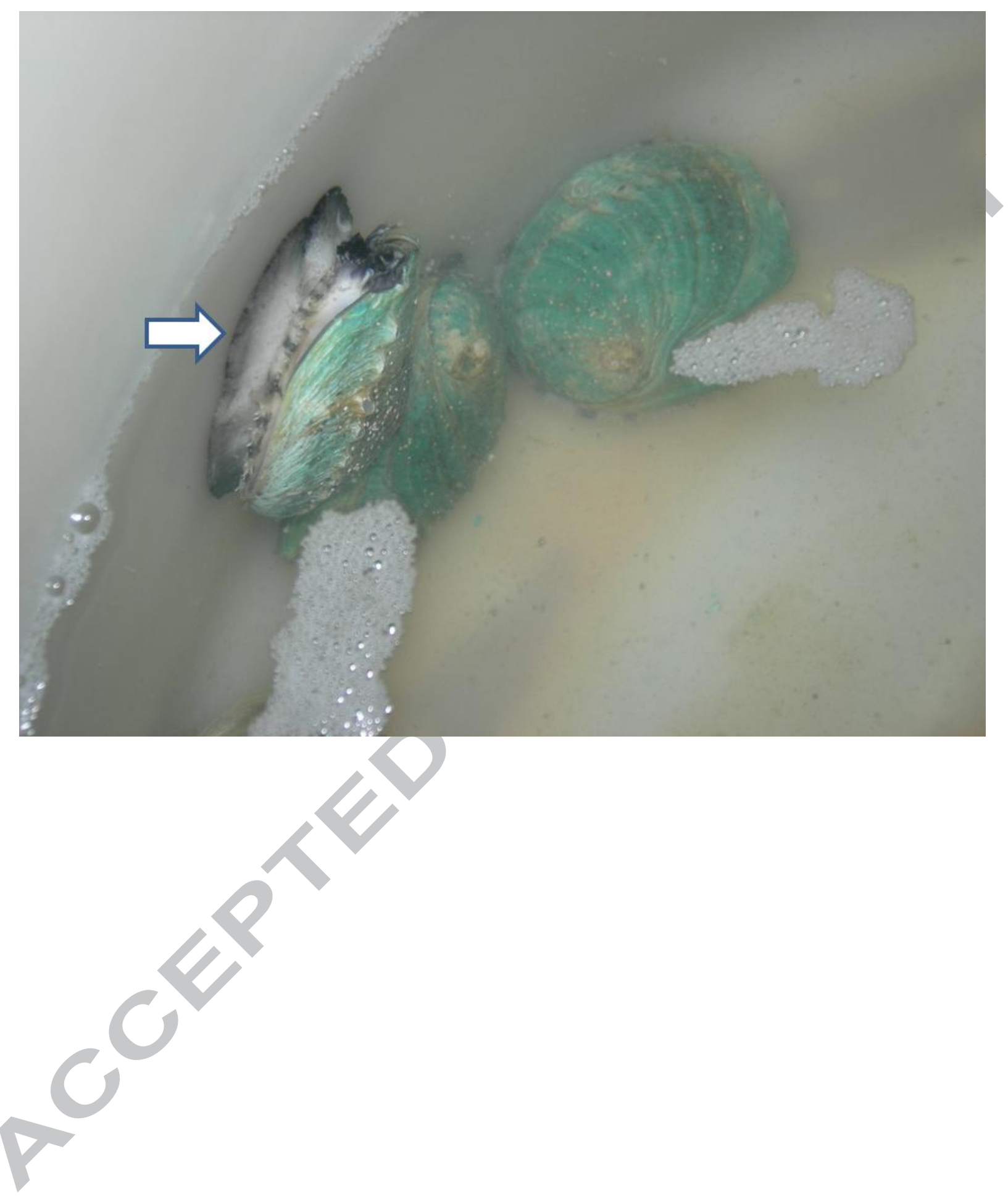




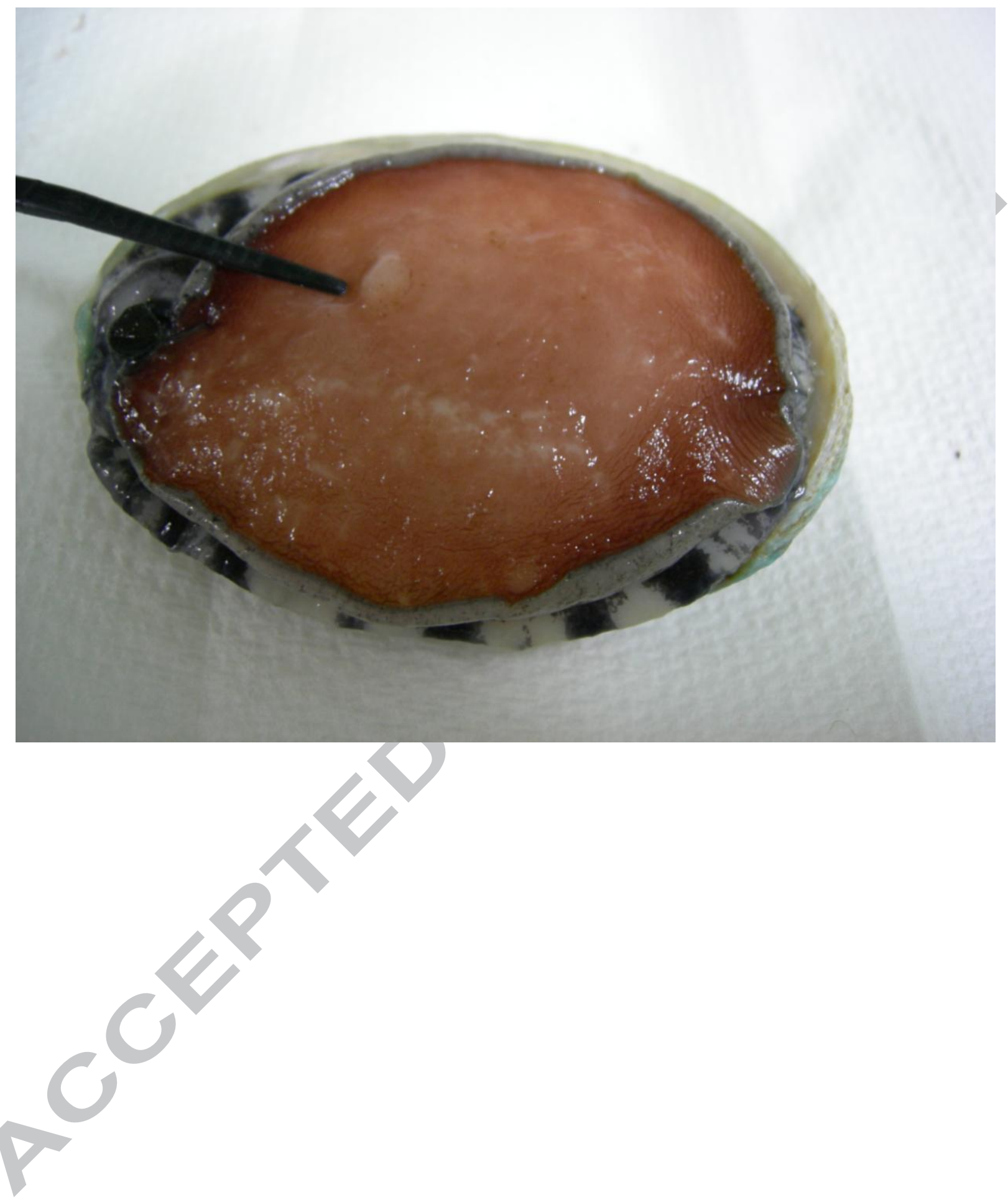




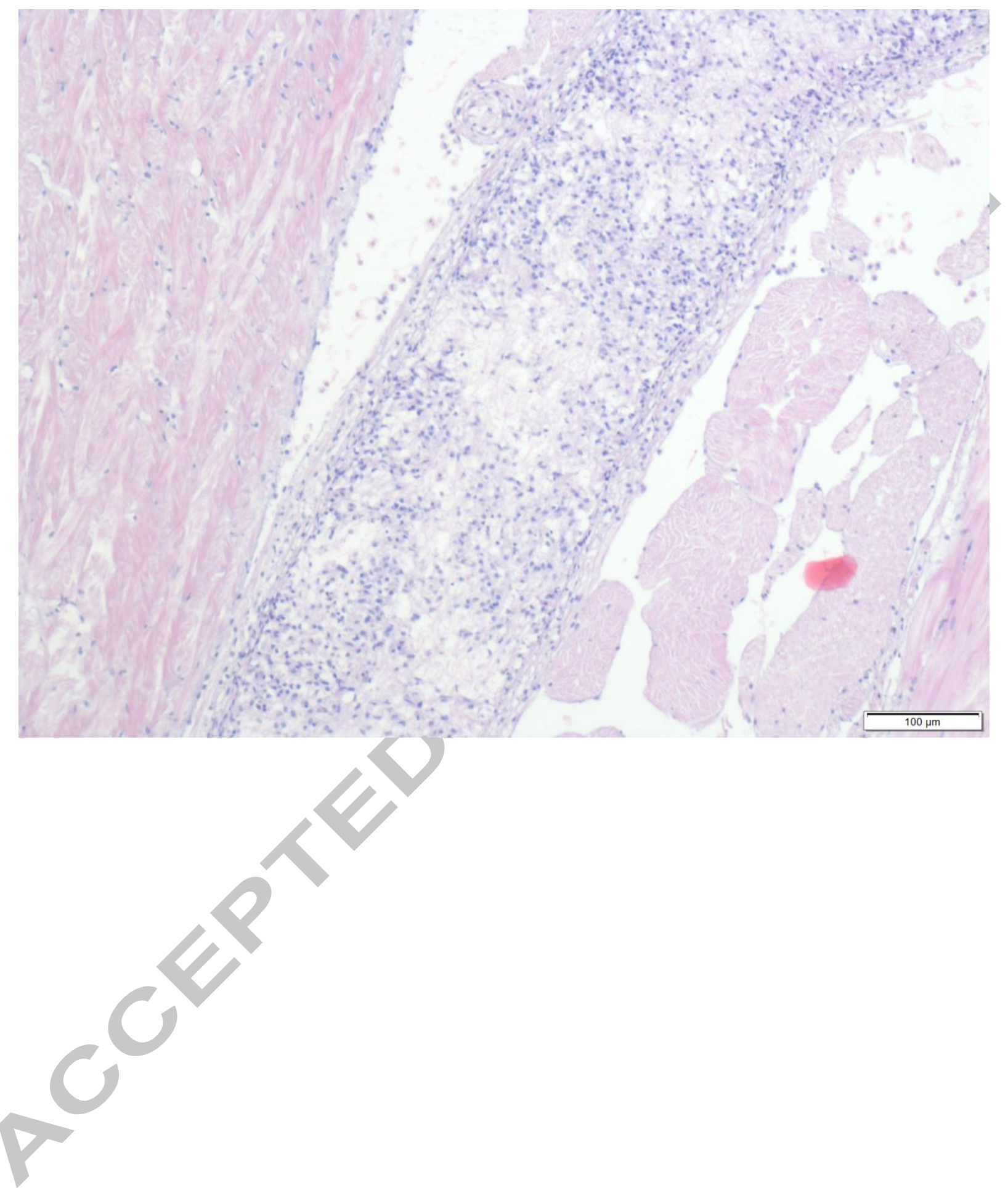



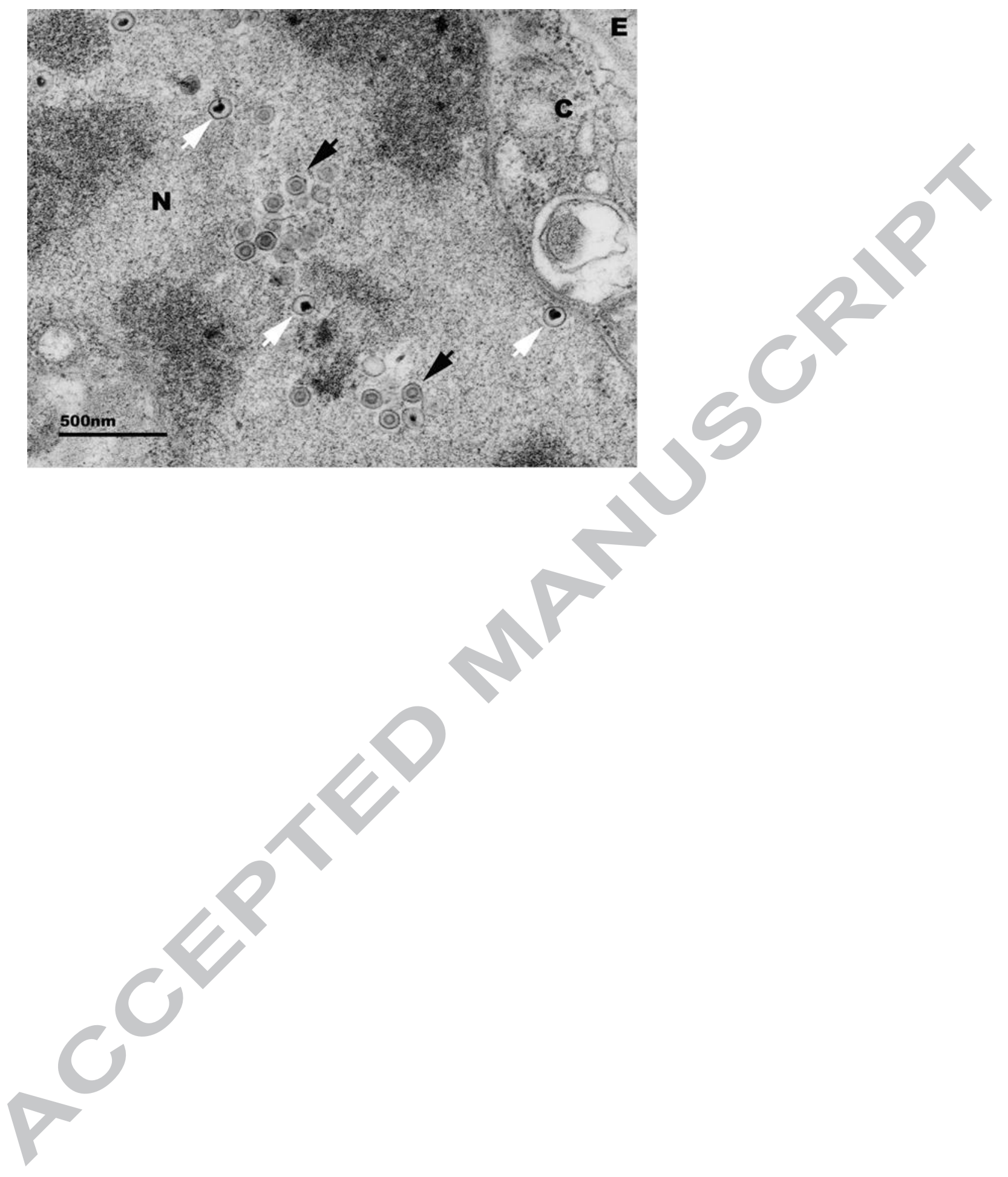